\title{
Carbon and nitrogen flows during a bloom of the coccolithophore Emiliania huxleyi: Modelling a mesocosm experiment
}

\author{
P. Joassin ${ }^{\text {a,* }}$, B. Delille ${ }^{\mathrm{b}}$, K. Soetaert $^{\mathrm{c}}$, J. Harlay ${ }^{\mathrm{b}, \mathrm{d}}$, A.V. Borges ${ }^{\mathrm{b}}$, L. Chou ${ }^{\mathrm{d}}$, U. Riebesell ${ }^{\mathrm{e}}$, \\ K. Suykens ${ }^{b}$, M. Grégoire ${ }^{a}$ \\ a Oceanology Laboratory, Interfacultary Centre for Marine Research, Université de Liège, Institut de Chimie (B6C), B-4000 Liège, Belgium \\ b Unité d'Océanographie Chimique, Interfacultary Centre for Marine Research, Université de Liège, Institut de Physique (B5), B-4000 Liège, Belgium \\ c Centre for Estuarine and Marine Ecology, Netherlands Institute of Ecology, Yerseke, The Netherlands \\ d Laboratoire d'Océanographie Chimique et Géochimie des Eaux, Université Libre de Bruxelles, Campus de la Plaine, Brussels, Belgium \\ e Leibniz Institute of Marine Sciences, IFM-GEOMAR, Kiel, Germany
}

\section{A R T I C L E I N F O}

\section{Article history:}

Received 24 June 2010

Received in revised form 26 November 2010 Accepted 30 November 2010

Available online 10 December 2010

\section{Keywords:}

Coccolithophore

Emiliania huxleyi

Mathematical model

Biogeochemical cycling

Calcification

Mesocosm experiment

\begin{abstract}
A B S T R A C T
A dynamic model has been developed to represent biogeochemical variables and processes observed during experimental blooms of the coccolithophore Emiliania huxleyi induced in mesocosms over a period of 23 days. The model describes carbon $(\mathrm{C})$, nitrogen $(\mathrm{N})$, and phosphorus $(\mathrm{P})$ cycling through $E$. huxleyi and the microbial loop, and computes $\mathrm{pH}$ and the partial pressure of carbon dioxide $\left(\mathrm{pCO}_{2}\right)$ from dissolved inorganic carbon (DIC) and total alkalinity (TA). The main innovations are: 1) the representation of E. huxleyi dynamics using an unbalanced growth model in carbon and nitrogen, 2) the gathering of formulations describing typical processes involved in the export of carbon such as primary production, calcification, cellular dissolved organic carbon (DOC) excretion, transparent exopolymer (TEP) formation and viral lyses, and 3) an original and validated representation of the calcification process as a function of the net primary production with a modulation by the intra-cellular $\mathrm{N}: \mathrm{C}$ ratio mimicking the effect of nutrients limitation on the onset of calcification. It is shown that this new mathematical formulation of calcification provides a better representation of the dynamics of TA, DIC and calcification rates derived from experimental data compared to classicaly used formulations (e.g. function of biomass or of net primary production without any modulation term).

In a first step, the model has been applied to the simulations of present $\mathrm{pCO}_{2}$ conditions. It adequately reproduces the observations for chemical and biological variables and provides an overall view of carbon and nitrogen dynamics. Carbon and nitrogen budgets are derived from the model for the different phases of the bloom, highlighting three distinct phases, reflecting the evolution of the cellular $\mathrm{C}: \mathrm{N}$ ratio and the interaction between hosts and viruses. During the first phase, inorganic nutrients are massively consumed by E. huxleyi increasing its biomass. Uptakes of carbon and nitrogen are maintained at a constant ratio. The second phase is triggered by the exhaustion of phosphate $\left(\mathrm{PO}_{4}^{3-}\right)$. Uptake of carbon and nitrogen being uncoupled, the cellular $\mathrm{C}: \mathrm{N}$ ratio of $E$. huxleyi increases. This stimulates the active release of DOC, acting as precursors for TEP. The third phase is characterised by an enhancement of the phytoplankton mortality due to viral lysis. A huge amount of DOC has been accumulated in the mesocosm.
\end{abstract}

(c) 2010 Elsevier B.V. All rights reserved.

\section{Introduction}

Past records reveal the presence of the coccolithophore Emiliania huxleyi for 270,000 years. During the last 70,000 years, it has become the most numerically important species of coccolithophores. It is abundant in most seas except for the Arctic and Antarctic oceans (Paasche, 2002). In addition to its worldwide distribution and its

\footnotetext{
* Corresponding author.

E-mail address: Pascal.Joassin@student.ulg.ac.be (P. Joassin).
}

presence through the ages, E. huxleyi populations are remarkable in their capacity to produce large blooms during which dissolved inorganic carbon (DIC) dynamics is affected by the fixation of carbon dioxide $\left(\mathrm{CO}_{2}\right)$ through primary production and the production of calcite (Paasche, 2002; Suykens et al., 2010; Harlay et al., 2011). Another typical characteristic of E. huxleyi is the production of transparent exopolymer particles (TEP), an organic substance rich in carbon, refractory to microbial degradation, that promotes aggregation (Passow, 2002). The convergence of these biological features makes E. huxleyi one of the major drivers of oceanic carbon export (Buitenhuis et al., 2001). 
Several models proposed and tested formulations describing the biogeochemical processes characteristic of phytoplankton blooms (e.g. Aksnes et al., 1994; Tyrrell and Taylor, 1996; Buitenhuis et al., 1996; Van Den Meersche et al., 2004; Merico et al., 2004; Oguz and Merico, 2006; Schartau et al., 2007). Buitenhuis et al. (2001) represent calcification by E. huxleyi during nitrate + nitrite $\left(\mathrm{NO}_{x}^{-}\right)$limited conditions to evaluate the DIC balance between photosynthesis and calcification. Van Den Meersche et al. (2004) describe carbon over-consumption, a typical feature in phytoplankton species, such as coccolithophores, under nutrient limited conditions (e.g. Toggweiller, 1993; Anderson and Sarmiento, 1994; Banse, 1994), and its impact on DIC dynamics. The cellular exudates resulting from carbon over-consumption may support chemical transformations, becoming the precursor of TEP (Engel et al., 2004a,b). Schartau et al. (2007) describe the different steps of the formation of TEP through the coagulation of acidic polysaccharides ( $\mathrm{PCHO}$ ) provided by the cellular exudates occurring in a mesocosm diatom bloom.

In the frame of larger biogeochemical scales, some models investigate the impact of coccolithophores in global ecological systems where other phytoplankton species are also represented. These models focus on factors triggering blooms and controlling their seasonal cycles (e.g. Aksnes et al., 1994; Tyrrell and Taylor, 1996; Merico et al., 2004; Oguz and Merico, 2006). They emphasize nitrogen cycling and the dynamics of coccolithophores is modelled using a carbon-nitrogen balanced growth model. For instance, in Merico et al. (2004) and Oguz and Merico (2006), the dynamics of E. huxleyi is represented by its nitrogen content. Therefore, these models of coccolithophores do not simulate the temporal decoupling between the uptake of carbon and nitrogen, although this decoupling has been observed in declining bloom conditions (Engel et al., 2005). Such an evolution of the models should be a pre-requisite for the representation of TEP dynamics via carbon over-consumption in order to better represent carbon export.

The model presented in this paper is developed to represent E. huxleyi blooms experimentally induced in a mesocosm experiment carried out in Bergen (Norway) in June 2001 (Engel et al., 2004a,b, 2005; Rochelle-Newall et al., 2004; Delille et al., 2005). The data set provided by this experiment (see Section 2.1 for details) allows testing and validating explicit formulations for all the mentioned processes. The model offers a tool to study the interactions between biogeochemical processes observed during a bloom of E. huxleyi: unbalanced carbonnitrogen phytoplankton growth leading to depletion of the limiting nutrient, exudation of carbon-rich dissolved organic matter (DOM) under nutrient limitation and formation of TEP induced by accumulation of carbon-rich DOM exudates.

The main innovations of the model consist in 1 ) the representation of $E$. huxleyi dynamics using an unbalanced growth model in carbon and nitrogen, 2) the gathering of formulations describing typical processes involved in the export of carbon such as primary production, calcification, cellular DOC excretion, TEP formation and viral lyses, 3 ) the use of an original and validated representation of the calcification process as a function of net primary production with a modulation by the intra-cellular $\mathrm{N}: \mathrm{C}$ ratio, and 4) a thorough validation of the above-mentionned process thanks to the large diversified data set available in a mesocosm frame. In most of past studies, the validation consists in comparing the simulated (nitrogen) biomass with chlorophyll-a (Chla) values without any validation of calcification and cellular excretion for instance.

The Bergen 2001 mesocosm experiment provided observations on E. hulxeyi blooms under present, high and low partial pressure of $\mathrm{CO}_{2}$ $\left(\mathrm{pCO}_{2}\right)$. This paper will only focus on simulations of experimental blooms induced in present-day $\mathrm{pCO}_{2}$ conditions. The objectives are 1) to derive well calibrated formulations of above-mentioned biogeochemical processes 2) to understand the bloom dynamics and 3) to derive a budget of carbon and nitrogen flows during the different phases of the bloom. After a relevant validation of the formulations used in regular conditions, the aim of future works will be to test these formulations also in acidified and low $\mathrm{pCO}_{2}$ conditions.

\section{Materials and methods}

\subsection{Experimental settings}

The study was carried out between 31 May and 25 June 2001 at the European Union Large Scale Facility (LSF) in Bergen, Norway. Nine outdoor polyethylene enclosures $\left(11 \mathrm{~m}^{3}, 4.5 \mathrm{~m}\right.$ depth) were moored to a raft in the Raunefjorden $\left(60.38^{\circ} \mathrm{N}, 5.28^{\circ} \mathrm{E}\right)$. The enclosures were filled with unfiltered, nutrient-poor, post-bloom fjord water, which was pumped from $2 \mathrm{~m}$ depth adjacent to the raft. The enclosures were covered by gas-tight tents which allowed for 95\% light transmission of the complete spectrum of sunlight, including ultraviolets A and B. The physical settings (temperature, light irradiance, and water turbulence) were similar in the nine enclosures (mesocosms). As the impact of increased atmospheric $\mathrm{pCO}_{2}$ on calcification and primary production was the main object of the experiment, the $\mathrm{pCO}_{2}$ inside the mesocosms enclosed atmosphere was controlled continuously during the experiment. The seawater carbonate chemistry was manipulated only at the start of the experiment, before the onset of the bloom, with a bubbling system of $\mathrm{CO}_{2}$-enriched air or $\mathrm{CO}_{2}$-free air at the bottom of the mesocosms. The triplicate mesocosm treatments represented glacial $\left(\sim 180 \mathrm{ppmV}\right.$ of $\left.\mathrm{CO}_{2}\right)$, present $(\sim 370 \mathrm{ppmV})$, and future $(\sim 700 \mathrm{ppmV})$ conditions of atmospheric $\mathrm{pCO}_{2}$. Mesocosms were numbered from 1 to 9 , and mesocosms 4,5 , and 6 correspond to present day $\mathrm{pCO}_{2}$ conditions. Initial mesocosms seawater was fertilized by adding $\mathrm{NO}_{x}^{-}$and $\mathrm{PO}_{4}^{3-}$. The water column of each mesocosm was actively mixed during the experiment. On 6th June, the fertilization of mesocosms seawater was terminated: $\mathrm{NO}_{x}^{-}$concentrations for mesocosms 4,5 and 6 were respectively $15.4,14.8,15.1 \mu \mathrm{mol} \mathrm{L}{ }^{-1}$, and $\mathrm{PO}_{4}^{3-}$ concentrations were respectively $0.46,0.51,0.48 \mu \mathrm{mol} \mathrm{L}^{-1}$, with an averaged $\mathrm{NO}_{x}^{-}$to $\mathrm{PO}_{4}^{3-}$ $(\mathrm{N}: \mathrm{P})$ ratio of 31 . Blooms dominated by the coccolithophore $E$. huxleyi occurred simultaneously in all mesocosms and was monitored over a 23 days period. The development of phytoplankton groups other than coccolithophores (Micromonas and Synechococcus) occurred at the start of the experiment in some mesocosms, the most important was by Micromonas. However, available data of $\mathrm{PO}_{4}^{3-}$ and $\mathrm{NO}_{x}^{-}$showed that the impact of this bloom on nutrients stocks was not significant. $\mathrm{NO}_{x}^{-}$ concentrations remained almost unchanged and Chla time-series only showed a slight increase during the Micromonas bloom. The rapid collapse of the E. huxleyi bloom in the mesocosms was assumed to be due to viral lyses, while grazing was not a significant removal term. The model was designed and calibrated to represent the bloom development under present-day $\mathrm{pCO}_{2}$ conditions and thus validation is only based on the measurements made in mesocosms numbered 4,5 , and 6 (summarized in Table 1). All variables were measured on a daily basis except for incoming photosynthetic active radiation (PAR), measured hourly.

\subsection{Mathematical model}

\subsubsection{Model structure}

The model describes $\mathrm{C}, \mathrm{N}$, and $\mathrm{P}$ cycling through E. huxleyi and the microbial loop. $\mathrm{NO}_{3}^{-}$and $\mathrm{NH}_{4}^{+}$are explicitly modelled as well as $\mathrm{PO}_{4}^{3-}$ in order to assess which inorganic nutrient, $\mathrm{P}$ or $\mathrm{N}$, was the most limiting for primary production during the experiment. The explicit modelling of $\mathrm{P}$ cycling including inorganic and organic forms of $\mathrm{P}$, is required to take into account the capacity of coccolithophores to consume labile and semi-labile dissolved organic phosphorus (respectively $\mathrm{DOP}_{\mathrm{L}}$ and $\mathrm{DOP}_{\mathrm{SL}}$ ) as well as $\mathrm{PO}_{4}^{3-}$ (Shaked et al., 2006; Xu et al., 2006; Zondervan, 2007). The DOM is divided into two pools: labile and semi-labile. TA and DIC are explicitly represented in order to obtain a description of DIC cycling and to evaluate the impact of calcification on TA. The model computes $\mathrm{pH}$ and $\mathrm{pCO}_{2}$ from DIC and TA. 
Table 1

Physical, chemical and biological variables determined during the Bergen 2001 mesocosm experiment.

\begin{tabular}{|c|c|c|}
\hline Variable & Method & References \\
\hline $\begin{array}{l}\lambda_{\text {PAR }} \\
\quad\left(\mu \mathrm{mol} \text { Photon } \mathrm{m}^{-2} \mathrm{~s}^{-1}\right)\end{array}$ & Spherical quantum sensor & Engel et al. (2005) \\
\hline$T\left({ }^{\circ} \mathrm{C}\right)$ & CTD & Engel et al. (2005) \\
\hline Salinity & CTD & Engel et al. (2005) \\
\hline $\mathrm{pCO}_{2}(\mathrm{ppmv})$ & $\begin{array}{l}\text { Equilibrator and Infrared } \\
\text { analyser }\end{array}$ & Delille et al. (2005) \\
\hline $\mathrm{TA}\left(\mu \mathrm{mol} \mathrm{kg}{ }^{-1}\right)$ & Titration & Delille et al. (2005) \\
\hline DIC $\left(\mu \mathrm{mol} \mathrm{kg}{ }^{-1}\right)$ & $\begin{array}{l}\text { Calculated from } \mathrm{pCO}_{2} \text { and } \\
\text { TA }\end{array}$ & Delille et al. (2005) \\
\hline $\mathrm{pH}_{\text {sws }}$ (seawater scale) & $\begin{array}{l}\text { Calculated from } \mathrm{pCO}_{2} \text { and } \\
\text { TA }\end{array}$ & Engel et al. (2005) \\
\hline $\mathrm{NO}_{x}+\mathrm{NH}_{x}\left(\mathrm{mmol} \mathrm{m}^{-3}\right)$ & Autoanalyser & Engel et al. (2005) \\
\hline $\mathrm{PO}_{4}^{3-}\left(\mathrm{mmol} \mathrm{m}^{-3}\right)$ & Autoanalyser & Engel et al. (2005) \\
\hline $\mathrm{DOC}\left(\mathrm{mmol} \mathrm{m}^{-3}\right)$ & Catalytic high combustion & (Engel et al., 2004a,b) \\
\hline $\mathrm{TEP}_{\mathrm{C}}\left(\mathrm{mmol} \mathrm{m}^{-3}\right)$ & Colorimetric analysis & (Engel et al., 2004a,b) \\
\hline PIC $\left(\mathrm{mmol} \mathrm{m}^{-3}\right)$ & CHN analyser (TPC-TOC) & Engel et al. (2005) \\
\hline $\mathrm{POC}\left(\mathrm{mmol} \mathrm{m}^{-3}\right)$ & CHN analyser & Engel et al. (2005) \\
\hline PON (mmol m $\left.{ }^{-3}\right)$ & $\mathrm{CHN}$ analyser & Engel et al. (2005) \\
\hline EhV density (part $\mathrm{m}^{-3}$ ) & Microscopy & $\begin{array}{l}\text { Rochelle-Newall et al. } \\
\text { (2004) }\end{array}$ \\
\hline $\begin{array}{l}\text { Bacterial density } \\
\quad\left(\text { part } \mathrm{m}^{-3}\right)\end{array}$ & Flow cytometry & $\begin{array}{l}\text { Rochelle-Newall et al. } \\
\text { (2004) }\end{array}$ \\
\hline Chla (mg Chla m ${ }^{-3}$ ) & Fluorometry & Engel et al. (2005) \\
\hline $\begin{array}{l}\text { E. huxleyi density } \\
\left(\text { cell }^{-3}\right)\end{array}$ & Flow cytometry & Engel et al. (2005) \\
\hline
\end{tabular}

Two forms of PIC are considered: the calcite attached to living cells and the free calcite resulting from dead cells or detached coccoliths. The model includes PCHO and $\mathrm{TEP}_{\mathrm{C}}$ dynamics as described by Engel et al. (2004a,b). It also involves a pool of E. huxleyi pathogen viruses (EhV)
(Jacquet et al. 2002). This compartment does not sustain a mass flux with the other compartments but its representation is needed to correctly simulate the termination of the bloom.

Since the water column of each mesocosm was actively mixed during the experiment, vertical gradients are neglected and a zerodimensional model is implemented. A schematic representation of the ecosystem model, indicating the different compartments and flows between them, is shown in Fig. 1. The model state variables (i.e. variables computed by resolving a diffential equation), the ordinary variables (i.e. variables directly computed from the state variables or the forcing variables using algebraic equations), the evolution equations for state variables, the equations of biogeochemical processes, and the parameters used in these formulations are listed and defined in Appendix Tables 2, 3, 4, 5 and 6, respectively.

\subsubsection{Description of biogeochemical processes}

2.2.2.1. Phytoplankton growth and microbial loop. E. huxleyi growth is described following an unbalanced growth model in carbon and nitrogen. DIC and nitrogen $\left(\mathrm{NO}_{x}^{-}+\mathrm{NH}_{4}^{+}\right)$uptakes are uncoupled (i.e. the cellular C: $\mathrm{N}$ ratio is variable within a certain range, parameters $\mathrm{NC}_{\mathrm{min}}$ and $\mathrm{NC}_{\text {max }}$ in Appendix Table 6, as described by Tett and Wilson, 2000), while phosphorus $\left(\mathrm{PO}_{4}^{3-}+\mathrm{DOP}_{\mathrm{L}}+\mathrm{DOP}_{\mathrm{SL}}\right)$ and nitrogen uptakes are coupled following a fixed cellular $\mathrm{N}: \mathrm{P}$ ratio. The $\mathrm{C}$ uptake is limited by DIC availability (Eq. (25)) while the uptake of $\mathrm{NO}_{3}^{-}$is inhibited by $\mathrm{NH}_{4}^{+}$ availability (Eqs. (27) and (28)). The uptake of $\mathrm{PO}_{4}^{3-}$ is computed from total $\mathrm{N}$ uptake following the cellular N:P Redfield ratio (Eq. (29)). The model considers the possibility for E. huxleyi to use $\mathrm{DOP}_{\mathrm{L}, \mathrm{SL}}$ (Eq. (30)). As suggested by Shaked et al. (2006) and $\mathrm{Xu}$ et al. (2006), $\mathrm{PO}_{4}^{3-}$ is assimilated preferentially to $\mathrm{DOP}_{\mathrm{L}, \mathrm{SL}}$ using an inhibition factor for $\mathrm{DOP} \mathrm{L}_{\mathrm{LS}}$ uptake. Chla concentrations are modelled as described in Soetaert et al.

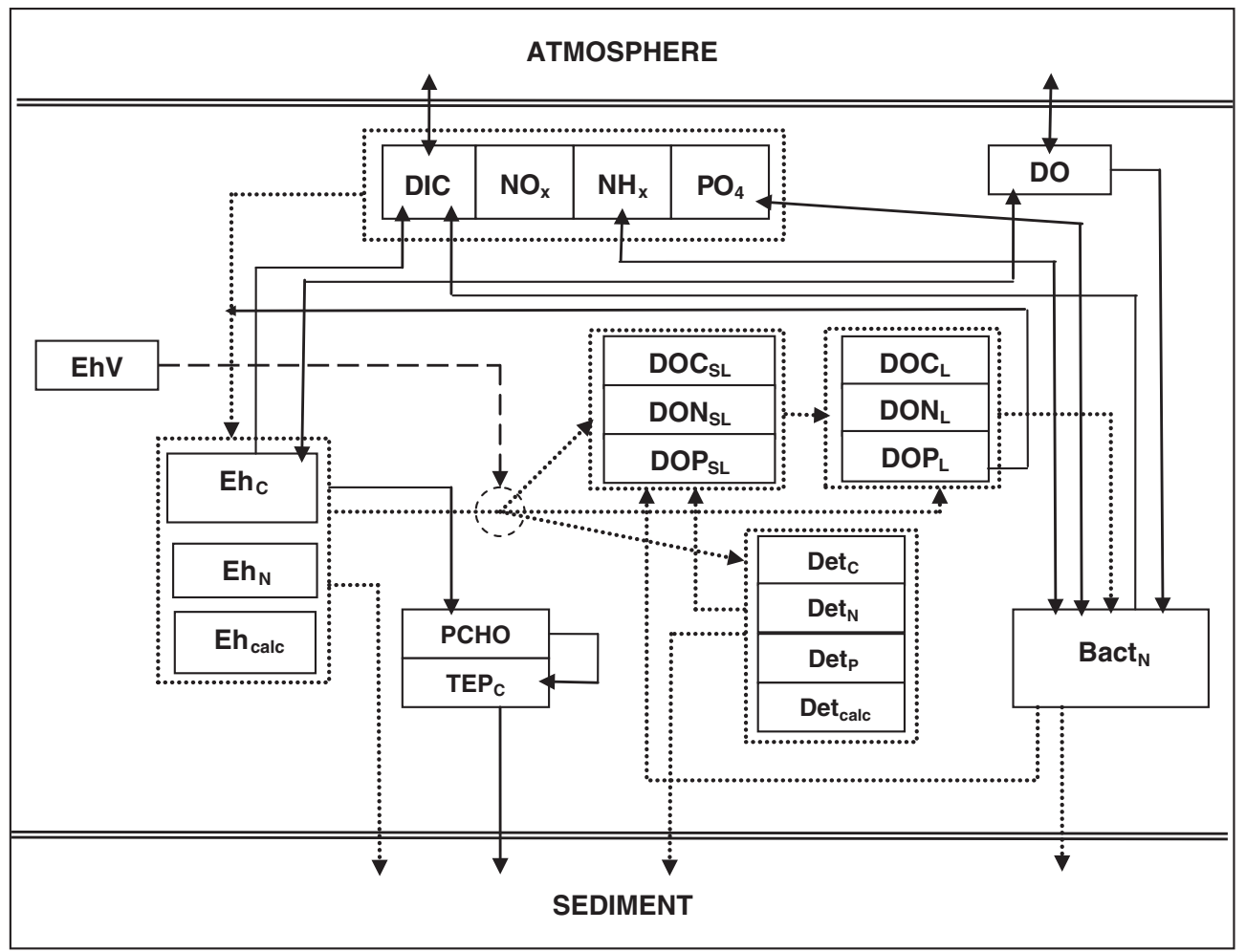

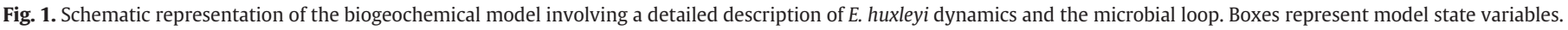

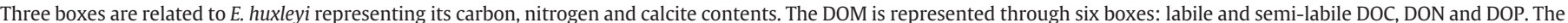



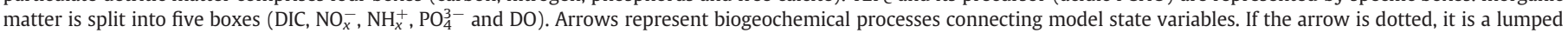
representation of carbon-nitrogen-phosphorus flows. The dash arrow represents the influence of viruses on the E.huxleyi mortality. 
(2001) and Van Den Meersche et al. (2004), depending on the phytoplankton concentration and the phytoplankton C:N ratio (Eq. (23)). E. huxleyi respiration consists in two terms: metabolic respiration and respiration required by cellular activity that is proportional to $C$ uptake (Eq. (26)). As suggested by Anderson and Williams (1998) and Van Den Meersche et al. (2004), bacterial dynamics is formulated using a balanced growth model in $\mathrm{C}$ and $\mathrm{N}$. Bacterial growth is sustained by $\mathrm{DOM}_{\mathrm{L}}$ and, in certain circumstances (i.e. high C: $\mathrm{N}$ ratio of $\mathrm{DOM}_{\mathrm{L}}$ ), they may also uptake $\mathrm{NH}_{4}^{+}$and $\mathrm{PO}_{4}^{3-}$. $\mathrm{DOM}_{\mathrm{SL}}$ needs to be hydrolyzed into $\mathrm{DOM}_{\mathrm{L}}$ before being taken up by bacteria.

2.2.2.2. DIC and TA dynamics. As explained by Soetaert et al. (2007), the model uses the total charge $\Sigma[-]$ rather than TA because if one assumes that uptake of ions is compensated by uptake or release of protons then $\Sigma[-]$ is not impacted by changes in the concentrations of $\mathrm{NO}_{3}^{-}, \mathrm{PO}_{4}^{3-}$ and $\mathrm{NH}_{4}^{+}$. This is not the case for TA (Soetaert et al., 2007). Because we do not consider $\Sigma \mathrm{SO}_{4}, \Sigma \mathrm{F}$, and $\Sigma \mathrm{NO}_{2}$ in the model, the relationship between TA and $\Sigma[-]$ is TA $=\Sigma[-]+\Sigma \mathrm{NH}_{4}-\Sigma \mathrm{NO}_{3}$. Also, DIC and $\Sigma[-]$ are the two model state variables from which $\mathrm{pH}_{\mathrm{sws}}$ and $\mathrm{pCO}_{2}$ are computed using dissociation constants of Mehrbach et al. (1973) refitted by Millero (1995) The solubility coefficient of $\mathrm{CO}_{2}$ at the prevailing temperature and salinity is calculated according to Weiss (1974). For additional details, an extensive description of the carbonate model is provided in Soetaert et al. (2007). At the experimental time scale of one month, the dynamics of $\mathrm{CO}_{2}$ is mostly determined by biological processes rather than by gas exchange across the air-sea interface. The absence of wind stress on the water surface reduces the diffusion rate of $\mathrm{CO}_{2}$ across the air-sea interface to molecular diffusion (Wanninkhof, 1992).

2.2.2.3. Carbon exudation and $T E P_{C}$ formation. E. huxleyi exudates $D O N_{L}$ and $\mathrm{DOC}_{\mathrm{L}}$ through passive leakage (Eqs. (35), (36) and (37), as in Van Den Meersche et al., 2004). E. huxleyi also exudates $\mathrm{DOC}_{\mathrm{L}}$ and $\mathrm{DOC}_{\mathrm{SL}}$ through active excretion. This last process is an active mechanism consisting in the exocytosis of high molecular weight substances mainly composed of organic carbon (PCHO) (Eq. (38)). This release of DOC reflects the carbon over-consumption. As described by Engel et al. (2004a,b), TEP formation is strongly linked to the cellular DOC excretion: a part of which (parameter $L_{t_{e e}}$ in Table 6) consists in acidic

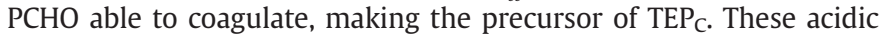
PCHO may also be directly adsorbed by existing $\mathrm{TEP}_{\mathrm{C}}$ (Eq. (5)). Coagulation and adsorption of acidic polysaccharides are modelled following equations given by Engel et al. (2004a,b). Also, the model state variable $\mathrm{PCHO}$ refers to acidic $\mathrm{PCHO}$ which is the fraction of cellular DOC excretion able to coagulate and acting as $\mathrm{TEP}_{\mathrm{C}}$ precursor.

2.2.2.4. Calcification. The model assumes that the calcifying activity of E. huxleyi is a structural cellular requirement induced by the normal growth of the cell. Following mesocosms experimental observations, the most efficient calcification is obtained when the cellular carbon growth is sustained under limited nutrients condition. Accordingly, the model describes the calcification as the combination of two terms (Eq. (39)): the main term is proportional to the net primary production (computed as the difference between DIC assimilation and respiration by E. huxleyi cells) using a constant calcite to cellular C ratio. This term is multiplied by a function of the cellular $\mathrm{N}: \mathrm{C}$ ratio disabling calcification when that ratio is equal to its maximum value. In addition, the model considers a minor term representing the permanent basal calcification as a function of the phytoplankton carbon biomass. Calcification leads to the production of coccoliths constituting the attached calcite. A part of these coccoliths are lost by detachment, providing the free calcite pool (Eq. (40)). Due to a protective carbohydrates envelop around the E. huxleyi cell (Godoi et al., 2009), attached calcite is preserved from dissolution in the coccosphere. Only free calcite is allowed to dissolve when the saturation state with respect to calcite $\left(\Omega_{\text {cal }}\right)$ drops below unit.
2.2.2.5. Viral lysis. Isolated, viruses have no capability of multiplication. They are only produced within infected phytoplankton cells and spread out when infected cells die. Hence, the model considers that the growth of the viral population is driven by the fraction of E. huxleyi mortality caused by viral infection (variable $R \eta_{\text {vir }}$ in Eq. (44)). A constant spread-out coefficient is applied to compute the number of new viruses released by dying infected cells (Jacquet et al., 2002). Once produced, the viruses keep their infecting potential for a limited time. The structural proteins of viruses are continuously degenerating, making an infection impossible after a certain time. This process is similar to a mortality affecting the viral population at a constant rate. The viral induced mortality is an additional term to the senescent mortality of E. huxleyi. The mortality caused by viruses is determined by a threshold function based on the encounter probability between viral agents and cellular hosts (Eqs. (43) and (44)) that rely on cell and virus densities.

2.2.2.6. Sedimentation. Despite the permanent mixing applied to the water column during the experiment, deposits were observed at the bottom of the mesocosms, as corroborated by the computation of carbon losses in the water column (Delille et al., 2005). Due to the small depth of the mesocosm $(4.5 \mathrm{~m})$ and the continuous bubbling applied during the whole experiment, we do not model explicitly the aggregation process between particulate materials. We impose rather constant sinking speeds for E. huxleyi cells, free PIC, TEP ${ }_{C}$, and detritus (Table 6). These sinking speeds were obtained from literature for E. huxleyi cells and free PIC (Paasche, 2002), or calibrated from the experimental measurements for $\mathrm{TEP}_{\mathrm{C}}$ and detritus. As explained in Section 2.2.4, this calibration exercise gives a small value for the sinking speed for $\mathrm{TEP}_{\mathrm{C}}$ more than one order of magnitude lower than that for detritus. To justify the use of a low sinking speed for $\mathrm{TEP}_{\mathrm{C}}$, we refer notably to the work of Engel et al. (2004a,b) who were able to reproduce the TEP dynamics observed during a mesocosm experiment considering the aggregation of $\mathrm{PCHO}$ and ignoring the vertical sinking of $\mathrm{TEP}_{\mathrm{C}}$. This can be justified by the fact that $\mathrm{TEP}_{\mathrm{C}}$ does not sink gravitationally (Engel and Schartau, 1999) but becomes attached to sinking particles and settles within aggregates. The model does not consider the degradation of the settled organic material, i.e. there are no fluxes of DIC and nutrients from the bottom deposit to the mesocosm water column.

\subsubsection{Model implementation and forcings}

Initial conditions for most of model state variables were directly obtained from the experimental data: DOC, POC, PON, TEP, , TA, DIC, PIC, $\mathrm{NO}_{x}^{-}, \mathrm{PO}_{4}^{3-}$, viral, bacterial, and $E$. huxleyi abundances. Initial organic carbon detritus ( Det $_{\mathrm{C}}$ ) was computed as the difference between the measured POC and the sum of $\mathrm{TEP}_{\mathrm{C}}$ and E. huxleyi carbon biomass. Conversion factors were used to derive $E$. huxleyi $\mathrm{C}$ biomass and bacterial $\mathrm{N}$ biomass from their respective abundances. The organic $\mathrm{C}$ content for bacteria was fixed to $1.0 \cdot 10^{-12} \mathrm{mmol} \mathrm{C}$ bact $^{-1}$ as proposed by Goldman et al. (1987) and the bacterial C:N ratio is fixed to 4 . The cellular organic $C$ content of $E$. huxleyi is calculated during the limited nutrients phase (day 10 to day 15) as the averaged ratio of the time variation of $\mathrm{POC}$ to the time variation of the abundance of $E$. huxleyi i.e. $(\mathrm{d}[\mathrm{POC}] / \mathrm{d} t) /(\mathrm{d}[\mathrm{E}$. huxleyi] $/ \mathrm{d} t)$. During this period, the increase of the POC concentration is largely dominated by the E. huxleyi development. Results given for this ratio are quasi similar for the three mesocosms. The mean value of $2.0 \cdot 10^{-9} \mathrm{mmol} \mathrm{cell}^{-1}$ was used during the entire simulation in order to convert the modelled $\mathrm{C}$ biomass into cellular abundance.

2.2.3.1. Forcing variables. Measurements of PAR at the surface were available hourly. An averaged value of PAR at half depth is calculated from the daily observation of the PAR profile and is used for the computation of the DIC uptake associated to photosynthesis. Other forcing variables measured daily during the experiment were temperature, salinity and $\mathrm{pCO}_{2}$ in the enclosed atmosphere. Since we are only interested in 
representing the dynamics of E. huxleyi, in order to minimize the effect of the Micromonas bloom on the DIC, TA, and nutrients, a nudging is applied for these variables, from day 1 to day 5 .

The model was implemented in FEMME (Flexible Environment for Mathematically Modelling the Environment, http://www.nioo.knaw. $\mathrm{nl} /$ node/513, Soetaert et al. (2002)). The model was integrated over the whole duration of the experiment (i.e. 23 days). Numerical computations were carried out using explicit Euler integration with a time step of $14 \mathrm{~min}$. Model outputs were stored hourly.

\subsubsection{Specific parameters and model calibration}

Model parameters are fine-tuned using an identifiability analysis. This allows selecting a parameter set that is identifiable with the available data. The model is found to be the most sensitive to $R_{\mu \mathrm{c}}, K_{\lambda}$, $E h_{\mathrm{SS}}$, and $t h_{E h V}$. These most sensitive parameters in addition with other parameters $\left(R_{\mathrm{uNOx}}, F_{\mathrm{Ccalc}}, P_{\mathrm{sll}}, R_{\eta \mathrm{bac}}, \eta_{\text {virmax }}\right.$, and $\left.R_{\eta}\right)$ are then calibrated with an automatic calibration procedure based on Levenberg-Marquardt algorithm. The variation range for parameters values is fixed between $\pm 20 \%$ and $\pm 50 \%$ of their nominal values following the uncertainty affecting the parameter. The procedure is repeated till convergence (Brun et al., 2002). E. huxleyi DIC uptake rate at $20{ }^{\circ} \mathrm{C}\left(R_{\mu \mathrm{C}}\right)$ is fixed to $0.11 \mathrm{~h}^{-1}$ in agreement with reported values ranging between 0.09 and $0.12 \mathrm{~h}^{-1}$ (Paasche, 2002; Merico et al., 2004). The parameter $R_{\text {calc }}$ controlling the basal calcification rate is obtained by fitting during the non-limited nutrients phase of the bloom, giving a value of $0.001 \mathrm{~h}^{-1}$. The parameter $F_{\text {Ccalc }}$ controlling the ratio between $E$. huxleyi calcite production and its organic $C$ growth is derived from the experimental data, giving a value of 1.9. The calibration procedure proposed a sinking speed of $0.015 \mathrm{~m} \mathrm{~h}^{-1}$ for the E. huxleyi cells. The sinking speed for $\operatorname{Det}_{C, N, P}$ and $\mathrm{TEP}_{\mathrm{C}}$ was linearly fitted in order to reproduce experimental observations concerning the $C$ losses in the mesocosms. The rates are $0.04 \mathrm{~m} \mathrm{~h}^{-1}$ and $0.002 \mathrm{~m} \mathrm{~h}^{-1}$ for $\operatorname{Det}_{\mathrm{C}, \mathrm{N}, \mathrm{P}}$ and $\mathrm{TEP}_{\mathrm{C}}$ respectively.

\section{Results and discussion}

The following results concern the application of the model in present-day $\mathrm{pCO}_{2}$ conditions ( $\left.410 \mu \mathrm{atm}\right)$. The Bergen 2001 mesocosm experiment provided a diversified data set essential to test conjointly several formulations about cellular processes of $E$. huxleyi. Observed TA and DIC allow the validation of parameters concerning calcification. Observed DIC and $\mathrm{TEP}_{C}$ allow the validation of parameters concerning DOC excretion and TEP ${ }_{C}$ formation. Observed $\mathrm{NO}_{x}^{-}$and $\mathrm{PO}_{4}^{3-}$ allow testing the formulation of inorganic nutrient uptakes by $E$. huxleyi. Observed DIC, nutrients and Chla allow assessing the dynamics of the uncoupling of $\mathrm{C}$ and $\mathrm{N}$.

\subsection{General description of model results: analysis of the three phases composing the bloom}

Model results show that the general pattern of carbon and nitrogen fluxes varies according to three phases. A first phase (between days 5 and 12) is characterised by the development of E. huxleyi population without any nutrients limitation. DIC and other inorganic nutrients are largely consumed and the E. huxleyi abundance increases. During the second phase (between days 12 and 16), $\mathrm{PO}_{4}^{3}$ stock becomes depleted and the bloom of E. huxleyi is sustained under inorganic nutrients limitation. Uncoupling between DIC and nutrients consumptions is observed as DIC is still consumed albeit nutrients uptake has stopped. During this second phase, E. huxleyi abundance keeps on increasing, reaches its maximum and then maintains a quasi-constant value. Finally, the third phase (between days 16 and 23) consists in a fast decrease of E. huxleyi abundance consequent to a viral attack rather than a natural cellular senescence.

The development of the E. huxleyi population during the first phase is observable through the exponential increase of both cellular abundance and Chla variables. All particulate variables (POC, PON and POP) also increase and DIC slowly decreases. This decrease of DIC is quite moderate because the E. huxleyi abundance is not high enough to sustain a strong DIC uptake. Both $\mathrm{NO}_{x}^{-}$and $\mathrm{PO}_{4}^{3-}$ are consumed following the constant $\mathrm{N}: \mathrm{P}$ ratio imposed in the model. TA remains quasi unchanged close to its initial value, reflecting the absence of any significant calcifying activity during this nutrients non-limited phase. This is also attested by the unchanged PIC which remains at a quasi-zero level till the end of the first phase. $\mathrm{TEP}_{\mathrm{C}}$ slightly increases in the early phase consequent to a coagulation of the initial stock of PCHO. After this coagulation event, $\mathrm{TEP}_{\mathrm{C}}$ keeps a quasi-constant value till the end of the first phase. C:N ratio remains quasi unchanged close to its initial value of 6 attesting the Redfield balanced uptakes of DIC and nitrogen $\left(\mathrm{NO}_{x}^{-}\right.$and $\mathrm{NH}_{4}^{+}$) during this first phase. Stock of $\mathrm{NH}_{4}^{+}$becomes quasi totally consumed at the end of the first phase.

The second phase is triggered by the exhaustion of $\mathrm{PO}_{4}^{3-}$ with labile and semi-labile DOP stocks, which are consumable by E. huxleyi. This occurs while $\mathrm{NO}_{x}^{-}$is still available and thus $\mathrm{P}$ is the element limiting the development of the E. huxleyi population in these mesocosm experiments. Due to the coupling of $\mathrm{N}$ and $\mathrm{P}$ uptakes, the unavailability of $\mathrm{P}$ causes the cessation of $\mathrm{NO}_{x}^{-}$and $\mathrm{NH}_{4}^{+}$uptakes. DIC is still consumed due to the uncoupling of $\mathrm{C}$ and $\mathrm{N}$ uptakes. This second phase is thus characterised by the sharp increase of the $\mathrm{C}: \mathrm{N}$ ratio. The development of E. huxleyi population becomes only sustained by carbon provision. Both PON and POP are decreasing while POC keeps increasing. This is also reflected by the collapse of Chla, computed from the cellular nitrogen biomass, while the E. huxleyi abundance, computed from the cellular carbon biomass, keeps increasing. High cellular C:N ratio constrain the DIC uptake making that the increase of E. huxleyi abundance stops one day after the nutrient exhaustion. The DIC uptake is then able to compensate the carbon losses due to respiration, but is not anymore able to sustain a growth of the E. huxleyi population. Indeed, the E. huxleyi abundance becomes quasi constant and keeps its maximum value till the end of this second phase. Another consequence of this elevated cellular C:N ratio is the triggering of calcification and cellular DOC excretion. The decrease of TA is concomitant with the moment of inorganic nutrients $\left(\mathrm{PO}_{4}^{3-}\right)$ depletion, in parallel with an increase of PIC, reflecting the mobilisation of bicarbonate ions to produce calcite. A sharp inflexion is also observable for $\mathrm{TEP}_{\mathrm{C}}$ in the early second phase. This $\mathrm{TEP}_{\mathrm{C}}$ increase is consequent to the coagulation of the huge quantity of DOC excreted by E. huxleyi growing under nutrient limitation. DOC and DON significantly increase during this second phase. DOC and DON stocks are mainly provided by the dissolution of POC and PON accumulated during the previous development of the E. huxleyi population.

The sharp increase of the viral density around day 16 initiates the third phase. Viruses are present since the beginning of the simulation but their multiplication requires high E. huxleyi abundance. These viruses become observable and cause significant E. huxelyi mortality only a few days after the abundance has reached its maximum. The enhanced cellular mortality due to viral lysis is responsible for the collapse of the E. huxleyi abundance observable in this third phase. Cellular activities such as calcification and DOC excretion are not directly impacted by the viruses. However, their external manifestations through the PIC and TEP productions become limited by the diminution of the E. huxleyi abundance. This is reflected by the stabilization of TA and DIC. In addition, TEP stops increasing and remain quasi constant due to the low sedimentation rate imposed in the model. PIC and POC variables reach their maximum in the early third phase and then decrease sharply due to the sinking of these particulate materials. Viral density peaks three days after the beginning of the third phase, and then collapses rapidly. This is due to the low E. huxleyi abundance at the end of the third phase leading to a dramatic decrease of the production rate of new viruses. 


\subsection{Comparison of model outputs and experimental observations}

In this section, we will compare model outputs with observations collected during the mesocosm experiment. In Section 3.3, we will discuss and explain the differences between both.

\subsubsection{Phytoplankton growth}

Modelled and observed E. huxleyi abundances are globally timephased: both maxima are reached around day 16 (Fig. 2). However, abundance tends to be slightly overestimated in the model. The model gives a good representation of POC corresponding to the sum of
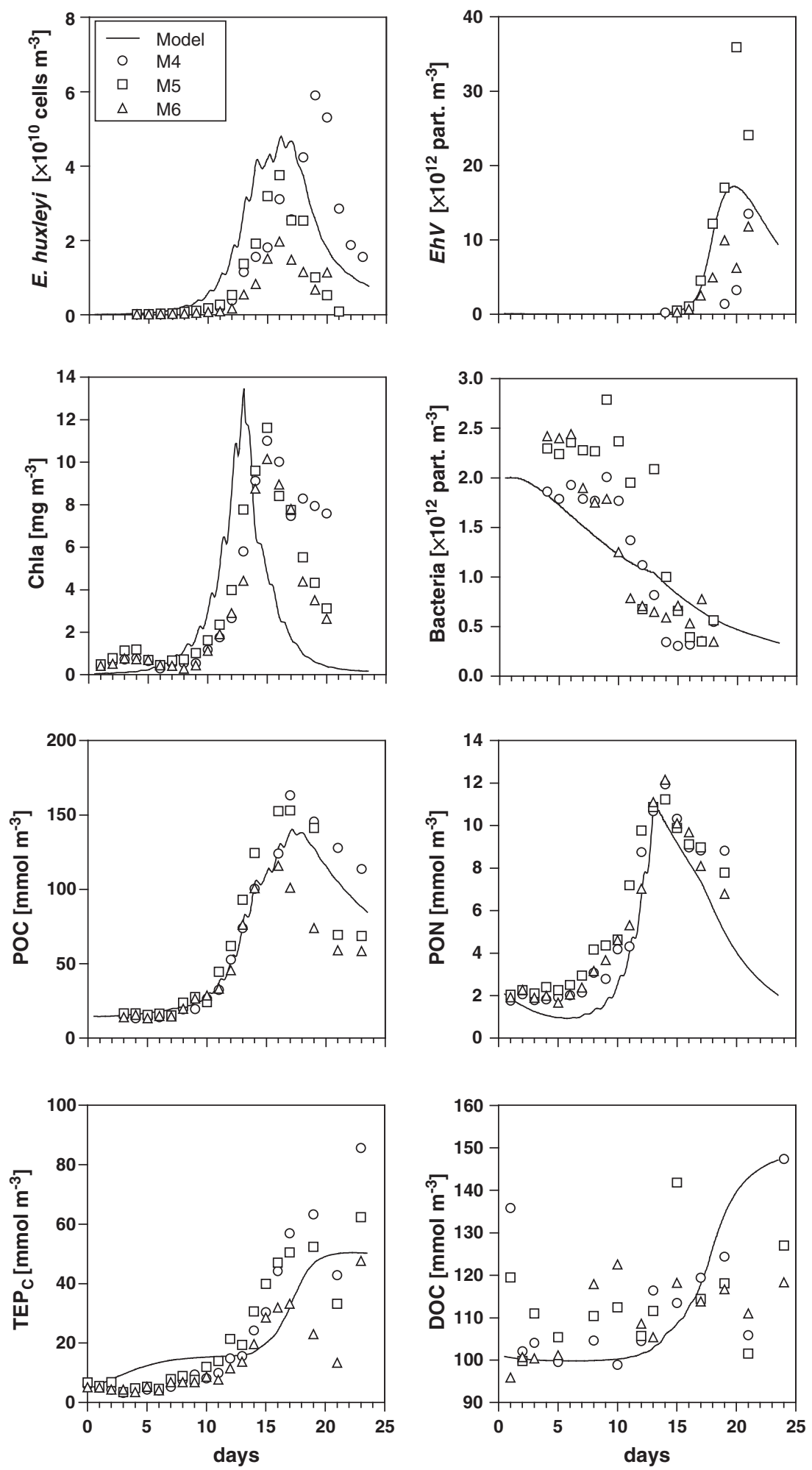

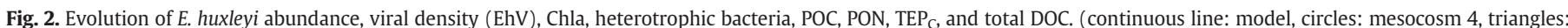

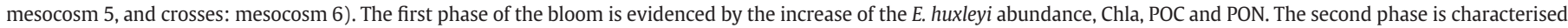


the E. huxleyi abundance and the raise of the viral density. 
E. huxleyi carbon biomass, carbon detritus and TEPC. Modelled and observed POC are very close till the moment of nutrients limitation. After, observed POC values between mesocosms become quite divergent. The model follows the decreasing trend of the observations and remains within the range (Fig. 2). Modelled and observed PON are well time-phased: both peak on day 14 (Fig. 2). The model tends however to underestimate the amount of PON during the first phase of the simulation. Modelled Chla is in the range of observations although it peaks slightly earlier in the model and then decreases faster than in the observations (Fig. 2). The slight increase of Chla visible in the observations during the first 5 days of the experiment is due to the development of other phytoplankton groups (Micromonas and Synechococcus). The Chla peak associated to these phytoplankton groups represents only a tenth of the Chla peak observed during the bloom of E. huxleyi. These groups are not modelled. Modelled $\mathrm{NO}_{x}^{-}$ and $\mathrm{PO}_{4}^{3-}$ are in agreement with the observations (Fig. 3). The observations show that phosphorus is the limiting nutrient for phytoplankton growth in all mesocosms. The model represents the phosphorus limitation: $\mathrm{PO}_{4}^{3-}$ as well as labile and semi-labile DOP are entirely consumed by E. huxleyi around day 10 .

\subsubsection{Microbial loop}

Model and observations show a global decrease of the bacterial population with a quasi-constant rate, evolving from initially $3.0 \cdot 10^{12}$ to $0.5 \cdot 10^{12}$ cells $\mathrm{m}^{-3}$ at the end of the experiment (Fig. 2). Bacterial growth highly depends on the availability of $\mathrm{DOM}_{\mathrm{L}}$ mainly provided by the phytoplankton mortality. Until day 16, labile organic substrates availability is not sufficient for an effective bacterial growth due to the low mortality rate of E. huxleyi cells. The sharp rise of phytoplankton mortality due to viral lyses after day 16 leads to a massive input of $\mathrm{DOM}_{L}$. However, bacterial growth is then constrained by the high $\mathrm{C}: \mathrm{N}$ ratio of the DOM released during this phase of the experiment. Consequently, bacteria shift to a competitive behavior with phytoplankton for inorganic nitrogen and phosphorus. Observed DOC shows a global increasing pattern, from initially 100 to $120 \mathrm{mmol} \mathrm{m}^{-3}$ at the end of the experiment. However, this pattern is not clearly depicted in the observations due to large differences between the three mesocosms (Fig. 2). The modelled DOC remains however within the range of the observations although the increase of DOC is much sharper in the model than in the observations. This increase is consequent to the enhancement of E. huxleyi mortality due to viral lyses after day 16 .

\subsubsection{Viruses}

The model succeeds to reproduce the multiplication of viruses: modelled and observed viral densities are close and time-phased (Fig. 2). In the model, the multiplication of viruses is triggered around day 16 , as a consequence of the elevated E. huxleyi abundance prevailing at the end of the limited nutrients phase of the bloom. Before day 16 , the modelled viral density remains at a quasi-zero level. This is in agreement with the observations from all the three mesocosms where the viral density sharply increases only between day 15 and day 17 . The viral density peaks around day 19 in the observations and the model, reaching a value of $15 \cdot 10^{12}$ part $\mathrm{m}^{-3}$. This corresponds to the maximal viral density observed in mesocosms 4 and 6 . After day 20, the observations show a sharp decrease of the viral density, falling to zero at the end of the experiment. The effective presence of viruses is thus restricted to a narrow period of three days, between day 17 and day 20. Compared to the observations, the modelled viral density decreases with a smoother slope after the peak, and viruses are still present at the end of the simulation.

\subsubsection{DIC and TA}

The observed DIC decreases from the beginning of the experiment. This trend is clearly enhanced after day 10 due to the massive development of the E. huxleyi. Phytoplankton groups other than
E. huxleyi (i.e. Micromonas) do not induce a marked impact on observed DIC during the early experiment. Till the moment of nutrients limitation, the decrease of DIC is not accompanied by a decrease of TA, revealing that DIC uptake is only due to primary production and not to calcifying activity. The observed DIC in the 3 mesocosms begins to diverge after day 15: in mesocosms 5 and 6, DIC stops decreasing, while DIC keeps on decreasing in mesocosm 4. Modelled DIC follows the observations trends and remains within their range during the whole simulation (Fig. 3). The DIC concentration at the end of the simulation is in agreement with the observations. However, observed DIC increases slightly in the three mesocosms during the last days of the experiment, and this pattern is not reproduced by the model.

The variation of TA reflects the uptake of bicarbonate ions sustained by E. huxleyi for the production of calcite. Observed TA remains quasi unchanged in the three mesocosms from the beginning of the experiment till the moment of $\mathrm{PO}_{4}^{3-}$ depletion around day 12 (Fig. 3). A sharp inflexion of the observed TA time-series is then visible on day 13 showing that the E. huxleyi calcification is suddenly triggered. Observed TA keeps on decreasing sharply for the next 4 days. Modelled TA remains within the range of the observations although these become highly variable between the 3 mesocosms during the viral termination of the blooms. The TA scenario that is presented by our simulation is in agreement with the viral lysis observed in mesocosm 5 (squares) in Figs. 2 and 3. The decrease of the modelled TA strongly slows down after day 18 but is maintained till the end of the simulation. The final modelled TA is close to the averaged final observed TA.

\subsubsection{DOC excretion and $T E P_{C}$ formation}

Observed $\mathrm{TEP}_{\mathrm{C}}$ increases slightly but continuously since the beginning of the experiment. This suggests the existence of TEP precursor in the environment, possibly produced by the smaller bloom of Micromonas that occurs at the early beginning of the experiment. Observed $\mathrm{TEP}_{C}$ shows a clear inflexion around day 13 , when $\mathrm{PO}_{4}^{3-}$ becomes depleted and induces nutrient limitation for primary production. Due to the balanced phytoplankton growth between nitrogen and phosphorus, the cessation of $\mathrm{PO}_{4}^{3-}$ uptake also stops nitrogen assimilation and increases the cellular C:N ratio. Elevated C:N ratio enhances cellular excretion of TEP precursor (PCHO), whose coagulation increases the amount of TEP $\mathrm{C}_{\mathrm{C}}$. The model reproduces that overall evolution but tends to overestimate $\mathrm{TEP}_{\mathrm{C}}$ early in the simulation (Fig. 2). Most of the modelled $\mathrm{TEP}_{\mathrm{C}}$ is produced during the nutrient limited phase of the bloom, and the slopes of observed and modelled TEP times-series are then quite similar.

\subsection{Discussion and analysis of processes}

\subsubsection{E. huxleyi dynamics: unbalanced growth}

An unbalanced growth model for carbon and nitrogen appears to be adapted to represent the development of E. huxleyi observed in the mesocom experiment. Observed time-series reveal that $\mathrm{pCO}_{2}$ keeps on decreasing at the same rate during two days after the occurrence of $\mathrm{PO}_{4}^{3-}$ depletion. This highlights the decoupling between the uptakes of $\mathrm{NO}_{x}^{-}$and DIC dedicated to photosynthesis by E. huxleyi, as far as $\mathrm{PO}_{4}^{3-}$ and $\mathrm{NO}_{x}^{-}$uptakes are balanced. The depletion of $\mathrm{PO}_{4}^{3-}$ prevents any assimilation of $\mathrm{NO}_{x}^{-}$that remains at a concentration of $0.5 \mathrm{mmol} \mathrm{m}^{-3}$ until the end of the experiment. This leads to an increase of the cellular C: $\mathrm{N}$ ratio which will have an impact on several cellular processes: the DIC fixation into living biomass becomes constrained and the cellular DOC excretion is enhanced. This unbalanced mechanism allows reproducing the general pattern of the E. huxleyi development observed during the mesocosm experiment.

A fixed cellular organic carbon content coefficient is used to convert the modelled E. huxleyi carbon biomass into abundance. The cellular organic carbon content is linked to the size of the cell. This size 
may be decreasing when the cellular growth is sustained under limited nutrient conditions (Engel et al. 2008) leading to a decrease of the cellular organic carbon content. However, since no precise information regarding the potential size of the cells is available from the mesocosm experiment, the comparison between model results and observations of E. huxleyi abundances relies on the assumption that the cellular organic carbon content of E. huxleyi cells remains unchanged during the whole experiment and fixed as explained in Section 2.2.3.

The modelled Chla starts to increase and peaks earlier compared to the observations. Afterwards, modelled Chla decreases faster than the observations. This difference can be explained by the fact that, in the
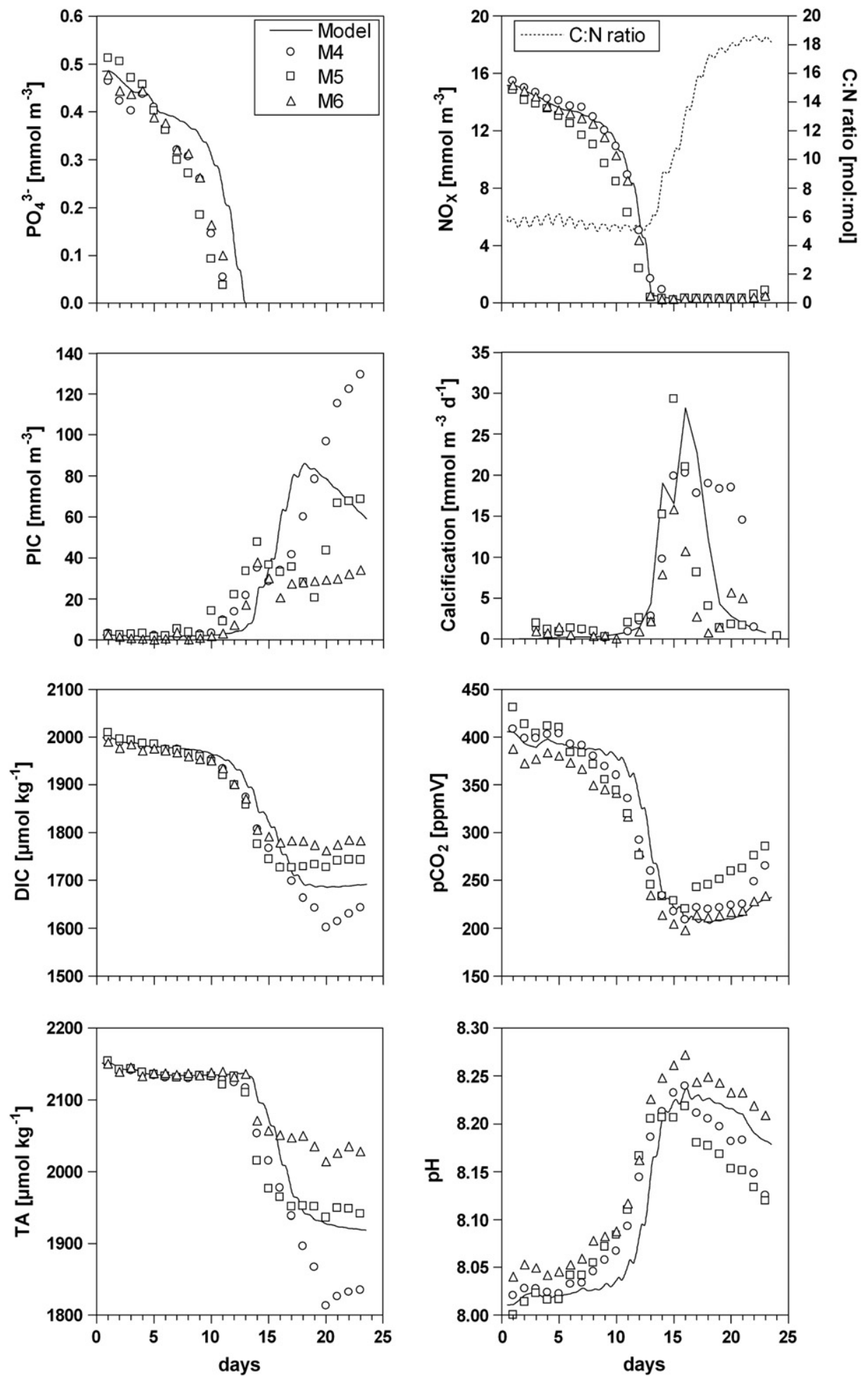

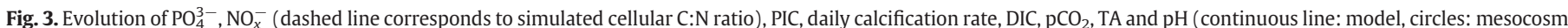

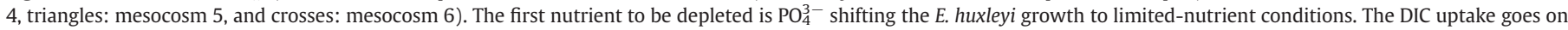


of TA, is concommitant with the raise of the cellular C:N ratio. 
a)

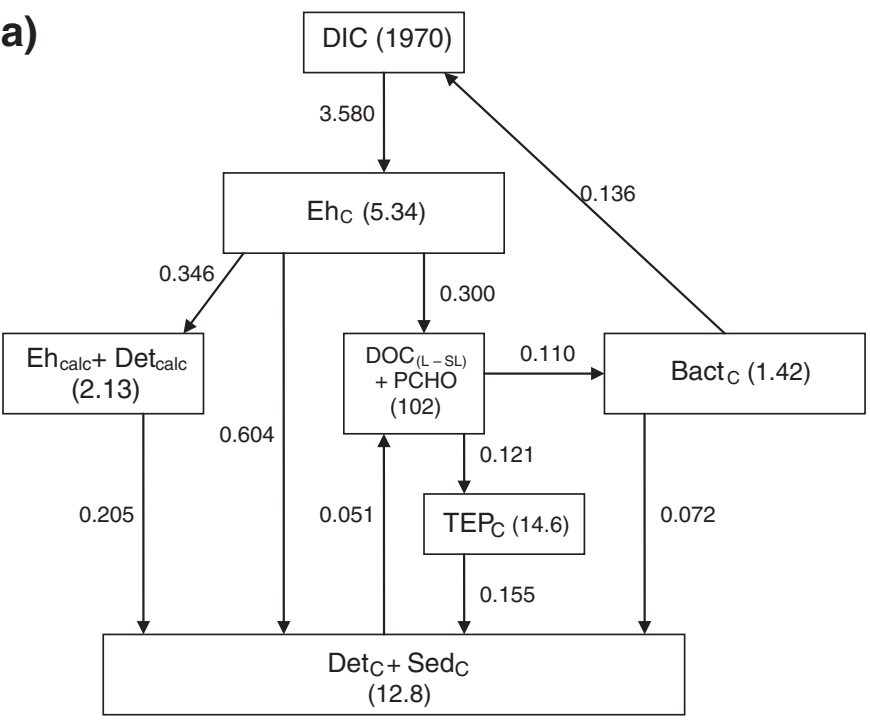

b)

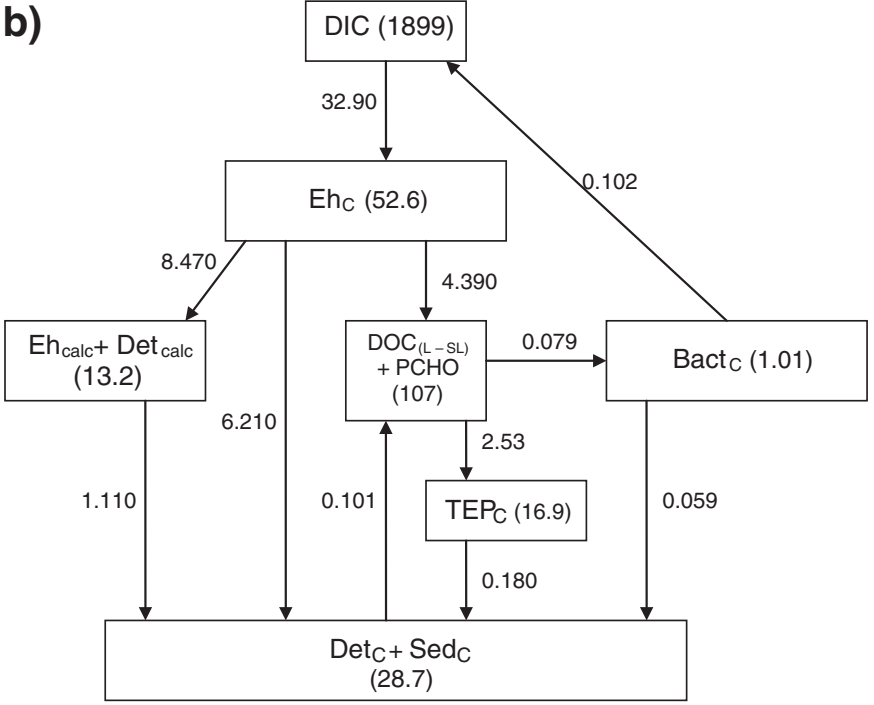

c)

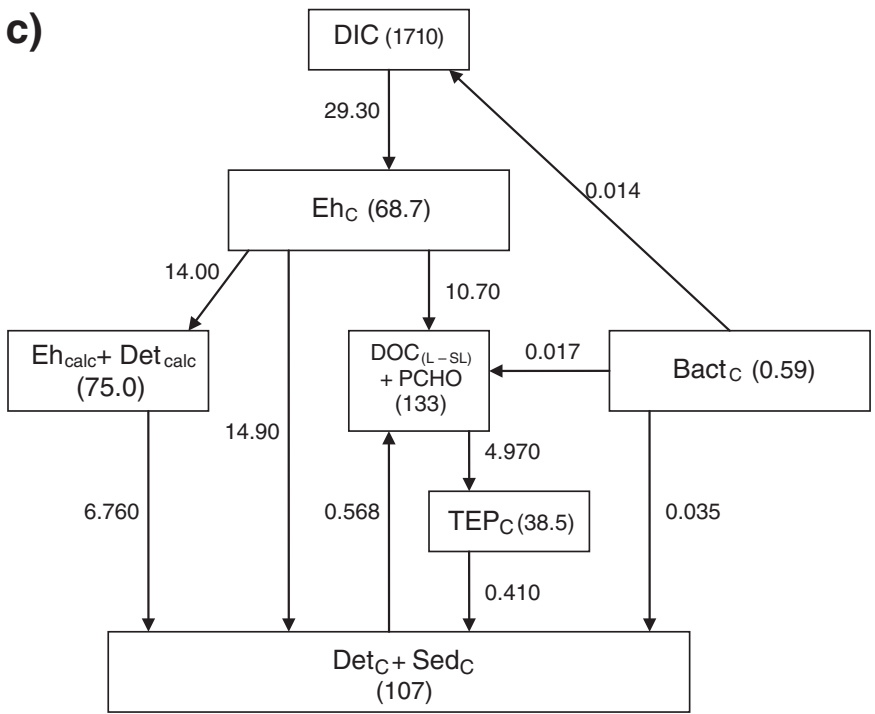

d)

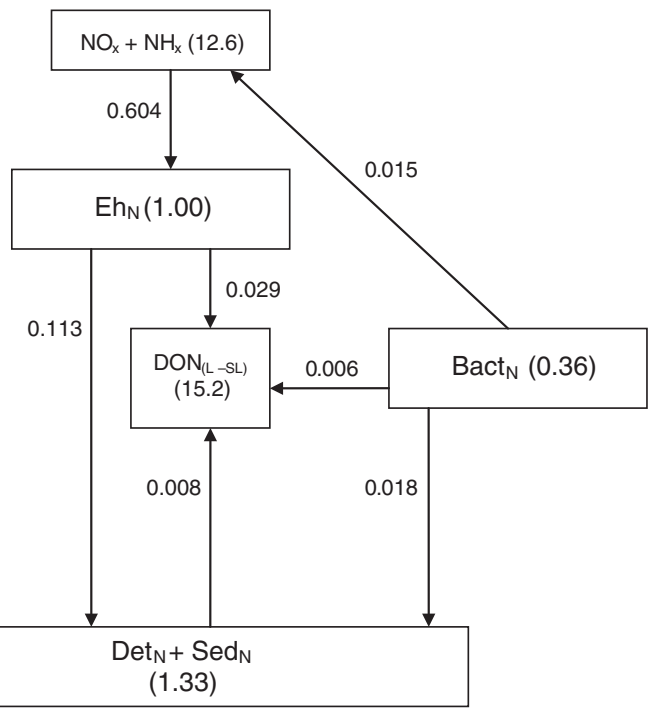

e)
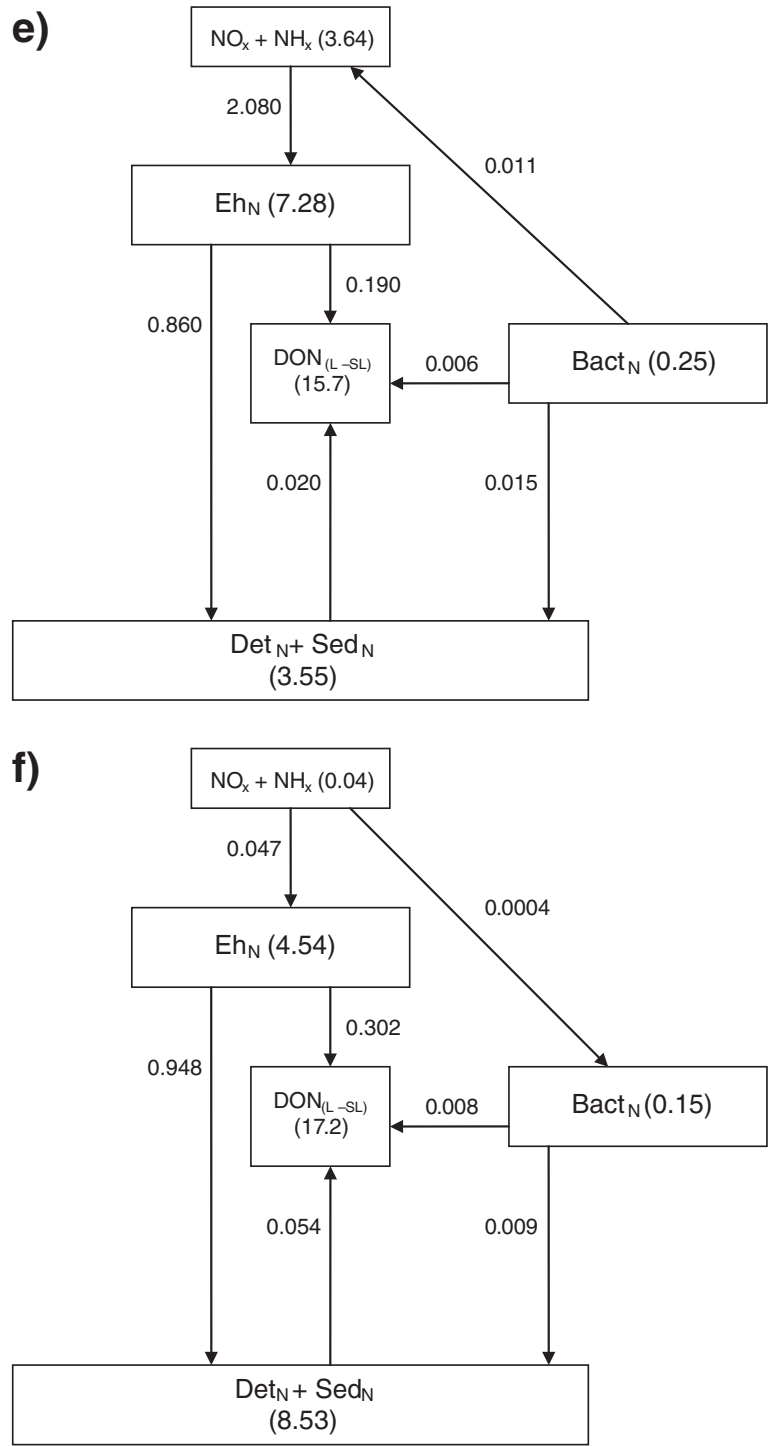



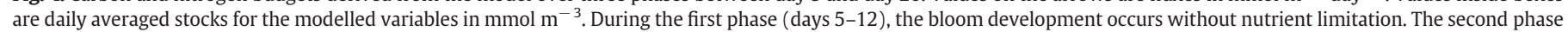

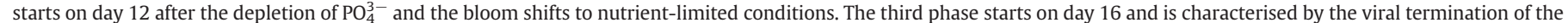
bloom. 
final phase of the bloom, the major part of Chla observed in the water column is not included in living cells while model computes Chla only from living cells. Besides, in the model, Chla is not dynamically computed but is deduced from phytoplankton carbon biomass (Eq. (23)). These two reasons may explain the underestimation of modelled Chla after the collapse of the E. huxleyi population around day 16.

The model does not consider diagenetic processes in the deposits on the bottom of the mesocosms. Processes that affect DIC, such as the bacterial respiration or $\mathrm{CaCO}_{3}$ dissolution, are only represented in the mesocosm water column. Also, material that reaches the bottom is not degraded and is definitely lost. This could explain the divergence between modelled and observed evolutions of DIC and $\mathrm{pCO}_{2}$ from day 18 till the end of the experiment: observed DIC and $\mathrm{pCO}_{2}$ values increase slightly, probably due to degradation of organic carbon in bottom deposits, while the model does not reproduce these trends.

\subsubsection{Calcification}

Following the formulation used in the model, calcification is conjointly determined by the evolution of the cellular C:N ratio and by the intensity of the primary production. The dynamics of calcification shown by the model is in agreement with the observations. The decrease of modelled TA occurs within a narrow time window (between days 12 and 16) concomitantly with the nutrient exhaustion and the parallel raise of the cellular $\mathrm{C}: \mathrm{N}$ ratio (Fig. 3 ). In the observations, the production of calcite, reflected by the decrease of TA, starts around day 12 and ends on day 16. Most of the calcite is produced during only 4 days, which implies high daily calcification rates during this period. Modelled rates are in agreement with the estimates of Delille et al. (2005) based on the change of TA corrected for inorganic nutrient assimilation (Fig. 3). The model shows a good representation of the calcification onset: modelled and observed PIC rise concomitantly, as it is also attested by the decrease of TA. This good agreement suggests that the triggering of the calcifying activity is mainly dependent on the cellular C: $\mathrm{N}$ ratio. Decoupling between DIC and nitrogen uptakes is thus necessary to represent a good time-phasing of the onset of calcification. Whether the cellular $\mathrm{C}: \mathrm{N}$ ratio controls the initiation of the calcification, the function of primary production introduced in the formulation is able to determine the evolution and the termination of the calcification. Using such a formulation, calcification is maintained as long as primary production of $E$. huxleyi occurs. The delay between the onset of calcification and the peak of $E$. huxleyi abundance suggests that a representation of calcification should not be based only on the cellular $\mathrm{C}$ biomass. On the contrary, the good agreement between model and the observations shows that an accurate representation of the calcification dynamics is obtained with a formulation linked to primary production and nutrient limitation.

Fig. 5 compares modelled TA and calcification rates using three different formulations for the representation of calcification. A first formulation is based only on the E. huxleyi carbon biomass with a calcification rate optimized to $0.01 \mathrm{~h}^{-1}$ (identified in Fig. 5 as Model a). This formulation anticipates the onset of the calcifying activity. The calcification is also sustained for too long leading to a clear underestimate of the TA at the end of the simulation. The second formulation applies the formulation used in the model but without the modulation by the cellular $\mathrm{N}: \mathrm{C}$ ratio, thus using only the term $\mathrm{F}_{\text {Ccalc. }}$ (net primary production) (identified in Fig. 5 as Model b). This formulation satisfactorily represents the intensity of the calcification. The modelled TA is indeed in the range of the observations at the end of the simulation. However, the weakness of this formulation is that it anticipates again the onset of the calcifying activity: modelled TA decreases three days before the observed TA. This leads to an underestimation of the TA during the nutrient non-limited phase of the bloom. The third formulation (function of net primary production and modulated by cellular $\mathrm{N}: \mathrm{C}$ ratio as used in the present study, same


Fig. 5. Comparision of $\mathrm{TA}$ and calcification rates simulated using three different formulations of calcification: a) as function of E. huxleyi carbon biomass (with param $R_{\text {calc }}$ adapted to $0.01 \mathrm{~h}^{-1}$ ); b) applying the formulation used in the model but ignoring the modulation of the cellular $\mathrm{N}: \mathrm{C}$ ratio, thus using only the term $F_{\text {Ccalc. }}$ (net primary production); and c) as used in the model (function of primary production modulated by cellular N:C ratio, same as in Fig. 3).

as in Fig. 3, identified in Fig. 5 as Model c) provides the best timing for the onset of calcification, and calcification rate peaks on day 16 in fair agreement with the measured rates.

\subsubsection{DOC excretion and $T E P_{C}$ dynamics}

Products of the cellular DOC excretion are shared between the TEP precursors (i.e. acidic $\mathrm{PCHO}$ ) and the labile DOC pool. In the early phase of the experiment, observations show that $\mathrm{TEP}_{\mathrm{C}}$ is slightly produced but the major formation of $\mathrm{TEP}_{\mathrm{C}}$ is only triggered on day 12 , concomitantly with the onset of calcification. However, in the model, $\mathrm{TEP}_{\mathrm{C}}$ increases already significantly during the beginning of the simulation. This difference of behavior between model simulation and observations can be explained as follows. As explained in section "model description", the modelled $\mathrm{PCHO}$ is considered to be exclusively acidic $\mathrm{PCHO}$ resulting from cellular DOC excretion and having coagulating properties. In order to initialize this state variable, we use observations of PCHO for which it is not possible to identify the acidic coagulating part. Most of this initial stock of PCHO results from the remaining polysaccharides produced by a previous bloom (in the fjord source water). Also, we overestimate the initial stock of acidic PCHO leading to an early overproduction of $\mathrm{TEP}_{\mathrm{C}}$ compared to observations. Then, as $\mathrm{PO}_{4}^{3-}$ becomes depleted and the $E$. huxleyi cellular $\mathrm{C}: \mathrm{N}$ ratio begins to increase, the model sharply enhances cellular DOC excretion and thus the provision of acidic PCHO in the water column, leading to the major formation of $\mathrm{TEP}_{\mathrm{C}}$. In the final part of the experiment, the observations show a sudden decrease of $\mathrm{TEP}_{\mathrm{C}}$ after day 18 , probably due to a massive aggregating event between $\mathrm{TEP}_{\mathrm{C}}$ and detritus, and their removal from the water column. The model does not however represent any aggregating process and fails to represent this feature. 


\subsubsection{Virus}

Observations show that the collapse of E. huxleyi abundance and the raise of viral density are concomitant, attesting the viral termination of the bloom. This confirms that the impact of enhanced cellular mortality due to interaction between cells and viruses has to be considered in confined environments. The onset of the viral multiplication is driven by the promiscuity between viruses and cellular hosts. That promiscuity is highly dependent of the E. huxleyi abundance. This underlines the importance of the cellular carbon content making the conversion of the E. huxleyi carbon biomass into abundance. An overestimation of the cellular carbon content leads to an underestimation of the cellular abundance which can delay the viral multiplication. Observations show that the multiplication of viruses suddenly stops after day 20 . A possible reason is that the rate of virus production became lower than the rate of viral degeneration. The abundance of $E$. huxleyi dropped below the threshold required to maintain a sufficient promiscuity between viruses and hosts, a necessary condition for a high infecting rate. Another process enhancing the termination of the viral attack may also be the removal of viruses scavenged by aggregates, as export is enhanced at the very end of the experiment (a sudden decrease of both $\mathrm{TEP}_{\mathrm{C}}$ and POC concentrations is observed after day 18). In the model, the viral abundance peaks around the same day as in the observations (day 20). Afterwards, the modelled viral abundance decreases at lower rate compared to the observations. This is unrelated to the parameters describing the viral dynamics as far as they succeed to represent the triggering and increasing phase of the viral event. Actually, the model does not involve any representation of aggregation. This contributes to overestimate many variables at the end of the experiment, organic particles and $\mathrm{TEP}_{\mathrm{C}}$, as well as the abundance of viral particles.

\subsection{Carbon and nitrogen fluxes inside the mesocosms}

The model was used to derive carbon and nitrogen budgets for the three phases composing the bloom and described in Section 3.1. The first phase (nutrient non-limited phase) extends from day 5 till the complete consumption of $\mathrm{PO}_{4}^{3-}$ on day 12 . The second phase (nutrient-limited phase) extends from day 12 till the collapse of the $E$. huxleyi population due to the viral attack around day 16 . The third phase (viral termination phase) extends from day 16 till the end of the experiment. Fig. 4 shows for each phase the daily averaged carbon and nitrogen fluxes between the model compartments.

\subsubsection{First phase: nutrient non-limited phase (days 5-12)}

The nutrient non-limited phase is characterised by carbon and nitrogen fluxes, from DIC and $\left(\mathrm{NO}_{x}^{-}+\mathrm{NH}_{x}^{+}\right)$compartments to the E. huxleyi carbon and nitrogen biomass compartments, sustained with a relative ratio of 6 in agreement with the Redfield value. The major part (66\%) of the total E. huxleyi DIC uptake (3.58 $\mathrm{mmol} \mathrm{C}^{-3}$ day $^{-1}$ ) is used to increase the E. huxleyi carbon biomass. Minor parts of the DIC uptake, about $9 \%\left(0.346 \mathrm{mmolC}^{-3} \mathrm{day}^{-1}\right)$ and $8 \%(0.30 \mathrm{mmol}$ $\left.\mathrm{C} \mathrm{m}^{-3} \mathrm{~d}^{-1}\right)$, are related, respectively, to free and attached calcite production and to any form of cellular DOC excretion (passive leakage and active excretion). Consequently, calcite and $\mathrm{TEP}_{\mathrm{C}}$ production are very low during this first phase of the bloom. The remaining part of the DIC uptake (17\% or $0.60 \mathrm{mmol} \mathrm{C} \mathrm{m}^{-3} \mathrm{day}^{-1}$ ) consists in detritus accumulation in the water column or sedimentation. In parallel to the carbon fluxes, the nitrogen flux resulting of $\left(\mathrm{NO}_{x}^{-}+\mathrm{NH}_{\mathrm{x}}^{+}\right)$uptake is able to maintain a cellular $\mathrm{C}: \mathrm{N}$ ratio close to 5 . During this phase, the net mesocosm production is positive with E. huxleyi gross primary production exceeding the community respiration. The total flux of carbon that goes from the E. huxelyi compartment to detritic matter and sediment is $0.97 \mathrm{mmol} \mathrm{C} \mathrm{m}^{-3}$ day $^{-1}: 0.21 \mathrm{mmol} \mathrm{C} \mathrm{m}^{-3}$ day $^{-1}$ $(21 \%)$ in inorganic form (free and attached calcite) and $0.60+$
$0.16 \mathrm{mmol} \mathrm{C} \mathrm{m}^{-3} \mathrm{day}^{-1}$ (79\%) in organic form (sinking cells, cellular mortality and TEP).

\subsubsection{Second phase: nutrient-limited phase (days 12-16)}

After day $12, \mathrm{PO}_{4}^{3-}$ is entirely consumed. The flux from $\mathrm{NO}_{x}^{-}$is unable to maintain a cellular C:N ratio of 6 and $E$. huxleyi shifts into an unbalanced growth phase regarding carbon and nitrogen uptakes. The flux from DIC to the E. huxleyi compartment contributes to increase the E. huxleyi carbon biomass. However, only $42 \%$ of the total DIC uptake ( $32.90 \mathrm{mmol} \mathrm{C} \mathrm{m}^{-3}$ day $^{-1}$ ) is now dedicated to the carbon organic biomass growth. This second phase of the bloom is characterised by the onset of calcification as $26 \%(8.47 \mathrm{mmol}$ $\mathrm{C} \mathrm{m}^{-3}$ day $^{-1}$ ) of the DIC uptake is used to produce calcite. TEP $C$ production is also enhanced as a consequence of the increase of cellular DOC excretion, consisting in $13 \%\left(4.39 \mathrm{mmol} \mathrm{C} \mathrm{m}^{-3} \mathrm{day}^{-1}\right)$ of the DIC uptake. The cellular DOC excretion increases the DOC pool in the mesocosm causing the raise of the DOM C:N ratio. This reduces the excretion of $\mathrm{NH}_{4}^{+}$and remineralization of $\mathrm{PO}_{4}^{3-}$ by bacteria, making the limited nutrients condition more severe in the community. More than $7.50 \mathrm{mmol} \mathrm{C} \mathrm{m}^{-3} \mathrm{day}^{-1}$ constitutes the total flux of carbon that goes from the E. huxelyi compartment to detritic matter and sediment: $1.11 \mathrm{mmol} \mathrm{C} \mathrm{m}^{-3} \mathrm{day}^{-1}$ (15\%) is in the form of PIC and $6.21+$ $0.18 \mathrm{mmol} \mathrm{C} \mathrm{m}^{-3} \mathrm{day}^{-1}$ (85\%) is in organic carbon.

\subsubsection{Third phase: viral termination phase (days 16-23)}

The multiplication of viruses and the sharp decrease of the E. huxleyi density characterize the termination of the bloom. The concentration and the uptake of $\mathrm{NO}_{x}^{-}$are close to zero. On the other hand, uptake of DIC is sustained. However, carbon fluxes leaving the E. huxleyi compartment (cellular mortality and cellular DOC excretion) are now exceeding the DIC uptake leading to the decrease of the E. huxleyi carbon biomass. The enhanced E. huxleyi mortality caused by viruses increases the fluxes towards the detritus and sediments compartments. The final phase is globally characterised by an increase of the DOC pool. However, the development of the microbial loop is limited by the lack of nitrogen in the ecosystem: bacteria compete with E. huxleyi for inorganic nitrogen during this third phase. The total flux of carbon that goes from the $E$. huxelyi compartment to detritic matter and sediment exceeds $22.07 \mathrm{mmol} \mathrm{C} \mathrm{m}^{-3} \mathrm{day}^{-1}$ in which $6.76 \mathrm{mmol} \mathrm{C} \mathrm{m}^{-3} \mathrm{day}^{-1}$ (31\%) accounts for inorganic carbon and $14.90+0.41 \mathrm{mmol} \mathrm{C} \mathrm{m}^{-3}$ day $^{-1}$ (69\%) for organic carbon.

\section{Conclusions}

Experimental blooms of E. huxleyi induced in mesocosms and related biogeochemical processes were studied using a mechanistic model describing carbon, nitrogen and phosphorus cycling. The model involves a refined representation of biogeochemical processes associated to E. huxleyi dynamics including primary production, calcification, cellular DOC excretion, viral lyses and TEP $\mathrm{C}_{\mathrm{C}}$ formation. The large data-set collected during the experiment constitutes an ideal and unique framework to derive and test the mathematical formulations of the above-mentioned processes. The variability of the cellular C: $\mathrm{N}$ ratio governs the dynamics of most of these processes and this stresses the necessity of using an unbalanced growth model in carbon and nitrogen for describing E. huxleyi dynamics. Since it appears that calcification starts at the same time as the exhaustion of inorganic nutrients in the mesocosm, a new formulation of calcification as a function of primary production and modulated by the C:N ratio is proposed. This formulation has been found to give a better representation of the observed calcification rates, TA and DIC drawdowns compared to past formulations which were usually based on the biomass or on solely primary production. A correct representation of $\mathrm{TEP}_{\mathrm{C}}$ formation has been found tightly dependent on an accurate representation of the cellular DOC excretion by $E$. huxleyi. This last process is also conditioned by the variability of the 
cellular C:N ratio. The model succeeds in considering the interaction between $E$. huxleyi cells and pathogen viruses as the most probable cause of an enhanced mortality responsible of the termination of blooms in a confined environment.

The changes in carbon and nitrogen budgets highlighted three phases in the bloom dynamic reflecting the evolution of the cellular C: $\mathrm{N}$ ratio and the interaction between hosts and viruses.

The application of the model to the simulation of bloom in real conditions will of course require some adaptations (e.g. impact of zooplankton grazing on the bloom termination, aggregation mechanism, competition with other phytoplankton species, and viral attack). A particular aspect of the model specifically related to the confined environment is the interaction between E. huxleyi and viruses. Little information is available concerning the implication of viruses relative to blooms termination in open oceanic conditions. The lower cellular abundance prevailing in open conditions ( 1 to $8 \cdot 10^{6}$ cells $\mathrm{L}^{-1}$, as reviewed by Harlay et al., 2010), in contrast to mesocosms (up to $60 \cdot 10^{6}$ cells $L^{-1}$, Fig. 2), may lead to reconsider the explicit representation of the enhanced cellular mortality due to viral lysis. Anyway, this present model can be a good starting tool for applications in open conditions because it contains a well calibrated mechanistic representation of processes associated to E. huxleyi development and DIC dynamics. We also plan to test the present model for simulating the mesocosms observations (Bergern, 2001) obtained in high and low $\mathrm{pCO}_{2}$ conditions in order to appraise, from the model and data analysis, which eventual processes need a reparamterization.

\section{Acknowledgments}

The authors are grateful to Jean Pierre Gattuso for providing PAR data during the Bergen experiment and to Anja Engel for her contribution to this work. All the scientists involved in the Pelagic Ecosystem $\mathrm{CO}_{2}$ Enrichment Study (PeECE) 2001 mescosm experiment are gratefully acknowledged for providing the data used in the present work. This research was supported by the Belgian Foundation for Scientific research (F.R.S.-FNRS), the EU IP SESAME (contract no. 036949-2), the PEACE project (contract no. SD/CS/03A) financed by the Belgian Federal Science Policy and the EU IP CARBOOCEAN (GOCE511176). The authors thank the two anonymous reviewers for their comments on the manuscrit. M.G., A.V.B. and B.D. are research associates at the F.R.S-FNRS. This is the MARE publication $n^{\circ} 202$ and the NIOO publication $n^{\circ} 4919$.

\section{Appendix A. Mathematical formulation of the model}

Table 2

List of biogeochemical state variables, description, and units.

\begin{tabular}{|c|c|c|}
\hline State variables & Description & Units \\
\hline$E h_{[\mathrm{C}, \mathrm{N}]}$ & Emiliania huxleyi carbon and nitrogen biomass & $\mathrm{mmol} \mathrm{C,N} \mathrm{m}^{-3}$ \\
\hline Bact $_{\mathrm{N}}$ & Heterotrophic bacteria nitrogen biomass & $\mathrm{mmol} \mathrm{N} \mathrm{m}{ }^{-3}$ \\
\hline EhV & Viral density & part $\mathrm{m}^{-3}$ \\
\hline $\mathrm{PCHO}$ & Polysaccharides TEP precursors & $\mathrm{mmol} \mathrm{C} \mathrm{m}{ }^{-3}$ \\
\hline$T E P_{\mathrm{C}}$ & TEP & $\mathrm{mmol} \mathrm{C \textrm {m } ^ { - 3 }}$ \\
\hline $\mathrm{NO}_{x}$ & Nitrate & $\mathrm{mmol} \mathrm{N} \mathrm{m}{ }^{-3}$ \\
\hline$N H_{x}$ & Ammonium & $\mathrm{mmol} \mathrm{N} \mathrm{m}{ }^{-3}$ \\
\hline $\mathrm{PO}_{4}$ & Phosphate & $\mathrm{mmol} \mathrm{P} m^{-3}$ \\
\hline DIC & Dissolved inorganic carbon & $\mathrm{mmol} \mathrm{C} \mathrm{m}{ }^{-3}$ \\
\hline DO & Dissolved oxygen & $\mathrm{mmol} \mathrm{O}_{2} \mathrm{~m}^{-3}$ \\
\hline$T A$ & Total alkalinity & $\mathrm{mmol} \mathrm{m}^{-3}$ \\
\hline$D O C_{\mathrm{L}}, D O C_{\mathrm{SL}}$ & Labile and semilabile dissolved organic carbon & $\mathrm{mmol} \mathrm{C} \mathrm{m}{ }^{-3}$ \\
\hline$D O N_{\mathrm{L}}, D O N_{\mathrm{SL}}$ & Labile and semilabile dissolved organic nitrogen & $\mathrm{mmol} \mathrm{C} \mathrm{m}-3$ \\
\hline$D O P_{\mathrm{L}}, D O P_{\mathrm{SL}}$ & $\begin{array}{l}\text { Labile and semilabile dissolved organic } \\
\text { phosphorus }\end{array}$ & $\mathrm{mmol} \mathrm{C} \mathrm{m}{ }^{-3}$ \\
\hline$E h_{\text {calc }}$ & Attached calcite on Emiliania huxleyi cells & $\mathrm{mmol} \mathrm{C \textrm {m } ^ { - 3 }}$ \\
\hline $\operatorname{Det}_{\text {calc }}$ & Free calcite & $\mathrm{mmol} \mathrm{C \textrm {m } ^ { - 3 }}$ \\
\hline $\operatorname{Det}_{[\mathrm{C}, \mathrm{N}, \mathrm{P}]}$ & Carbon, nitrogen, phosphorus organic detritus & $\mathrm{mmol} \mathrm{m}^{-3}$ \\
\hline
\end{tabular}

Table 3

List of ordinary variables.

\begin{tabular}{|c|c|c|}
\hline Variables & Description & Units \\
\hline$T$ & Temperature & Celsius degree \\
\hline$S$ & Salinity & \\
\hline$Q_{T}$ & Temperature modulating factor & \\
\hline$\mu_{\mathrm{C}}$ & E. huxleyi DIC uptake & $\mathrm{mmol} \mathrm{m}{ }^{-3} \mathrm{~h}^{-1}$ \\
\hline Chla & Chlorophyll a & $\mathrm{mg} \mathrm{m}^{-3}$ \\
\hline$E h_{\mathrm{P}}$ & E. huxleyi phosphorus biomass & $\mathrm{mmol} \mathrm{m}^{-3}$ \\
\hline$\rho_{\text {Eh }}$ & E. huxleyi respiration & $\mathrm{mmol} \mathrm{m}{ }^{-3} \mathrm{~h}^{-1}$ \\
\hline NC & E. huxleyi $\mathrm{N}: \mathrm{C}$ ratio & $\mathrm{mol} \mathrm{mol}^{-1}$ \\
\hline$\lambda$ & Mesocosm half depth PAR & $\mu \mathrm{mol} \mathrm{m}{ }^{-2} \mathrm{~h}^{-1}$ \\
\hline$\mu_{\mathrm{NO}_{x}}$ & E. huxleyi $\mathrm{NO}_{x}$ uptake & $\mathrm{mmol} \mathrm{m}{ }^{-3} \mathrm{~h}^{-1}$ \\
\hline$\mu_{\mathrm{NH}_{x}}$ & E. huxleyi $\mathrm{NH}_{x}$ uptake & $\mathrm{mmol} \mathrm{m}{ }^{-3} h^{-1}$ \\
\hline$\mu_{P_{4}}$ & E. huxleyi $\mathrm{PO}_{4}$ uptake & $\mathrm{mmol} \mathrm{m}{ }^{-3} \mathrm{~h}^{-1}$ \\
\hline$\mu_{\mathrm{DOPI}}$ & E. huxleyi $D O P_{\mathrm{L}}$ uptake & $\mathrm{mmol} \mathrm{m}{ }^{-3} \mathrm{~h}^{-1}$ \\
\hline$\mu_{\text {DOPsl }}$ & E. huxleyi $D O P_{\mathrm{SL}}$ uptake & $\mathrm{mmol} \mathrm{m}{ }^{-3} \mathrm{~h}^{-1}$ \\
\hline$\pi_{E h_{\text {C.N.PP }}}$ & E. huxleyi DOM passive leakage & $\mathrm{mmol} \mathrm{m}^{-3} \mathrm{~h}^{-1}$ \\
\hline$\tau_{\text {calc }}$ & Calcite production & $\mathrm{mmol} \mathrm{m}{ }^{-3} \mathrm{~h}^{-1}$ \\
\hline$\Omega_{\text {calc }}$ & Calcite saturation state & - \\
\hline$\tau_{\text {detach }}$ & Coccoliths detachment & $\mathrm{mmol} \mathrm{m}^{-3} \mathrm{~h}^{-1}$ \\
\hline$\tau_{\text {dissol }}$ & Calcite dissolution & $\mathrm{mmol} \mathrm{m}^{-3} \mathrm{~h}^{-1}$ \\
\hline$\tau_{\mathrm{ee}}$ & DOC extra excretion & $\mathrm{mmol} \mathrm{m} \mathrm{m}^{-3} \mathrm{~h}^{-1}$ \\
\hline$R_{\eta_{\text {vir }}}$ & E. huxleyi viral based mortality rate & $h^{-1}$ \\
\hline prox & E. huxleyi cells - viruses proximity & part $\mathrm{m}^{-3}$ \\
\hline$\eta_{E h_{(C, N . P]}}$ & E. huxleyi mortality & $\mathrm{mmol} \mathrm{m}^{-3} \mathrm{~h}^{-1}$ \\
\hline$\eta_{E h_{\text {calc }}}$ & E. huxleyi mortality based calcite losses & $\mathrm{mmol} \mathrm{m} \mathrm{m}^{-3} \mathrm{~h}^{-1}$ \\
\hline$\sigma_{E h_{[C, N, P]}}$ & E. huxleyi sedimentation & $\mathrm{mmol} \mathrm{m}^{-3} \mathrm{~h}^{-1}$ \\
\hline$\sigma_{E h_{\text {calc }}}$ & Attached calcite sedimentation & $\mathrm{mmol} \mathrm{m}{ }^{-3} \mathrm{~h}^{-1}$ \\
\hline$\sigma_{\text {det }} t_{\text {calc }}$ & Free calcite sedimentation & $\mathrm{mmol} \mathrm{m}^{-3} \mathrm{~h}^{-1}$ \\
\hline$\sigma_{T E P}$ & TEP sedimentation & $\mathrm{mmol} \mathrm{m} \mathrm{m}^{-3} \mathrm{~h}^{-1}$ \\
\hline$\sigma_{\operatorname{det}_{\text {C.N.PP }}}$ & Detritus sedimentation & $\mathrm{mmol} \mathrm{m}{ }^{-3} h^{-1}$ \\
\hline$\delta_{\operatorname{det}_{(C, N . P]}}$ & Decayed detritus & $\mathrm{mmol} \mathrm{m}{ }^{-3} \mathrm{~h}^{-1}$ \\
\hline$\delta_{N H_{x}}$ & Nitrification & $\mathrm{mmol} \mathrm{m}^{-3} \mathrm{~h}^{-1}$ \\
\hline Bact $_{\mathrm{C}}$ & Bacterial carbon biomass & $\mathrm{mmol} \mathrm{m}^{-3}$ \\
\hline Bact $_{\mathrm{P}}$ & Bacterial phosphorus biomass & $\mathrm{mmol} \mathrm{m}^{-3}$ \\
\hline$v_{D O M_{[C . N P Y}}$ & Potential bacteria $D O M_{\mathrm{L}}$ uptake & $\mathrm{mmol} \mathrm{m}^{-3} \mathrm{~h}^{-1}$ \\
\hline$v_{N H_{x}}$ & Potential bacterial $N H_{x}$ uptake & $\mathrm{mmol} \mathrm{m} \mathrm{m}^{-3} \mathrm{~h}^{-1}$ \\
\hline$v_{P_{4}}$ & Potential bacterial $\mathrm{PO}_{4}$ uptake & $\mathrm{mmol} \mathrm{m} \mathrm{m}^{-3} \mathrm{~h}^{-1}$ \\
\hline$\epsilon D O M_{[C, N, P]}$ & Effective bacterial $D O M_{\mathrm{L}}$ uptake & $\mathrm{mmol} \mathrm{m}{ }^{-3} h^{-1}$ \\
\hline$\epsilon N H_{x}$ & Effective bacterial $N H_{x}$ uptake or excretion & $\mathrm{mmol} \mathrm{m} \mathrm{m}^{-3} \mathrm{~h}^{-1}$ \\
\hline$\epsilon \mathrm{PO}_{4}$ & Effective bacterial $\mathrm{PO}_{4}$ uptake or excretion & $\mathrm{mmol} \mathrm{m}^{-3} \mathrm{~h}^{-1}$ \\
\hline$\rho_{\text {bact }}$ & Bacterial respiration & $\mathrm{mmol} \mathrm{m} \mathrm{m}^{-3} \mathrm{~h}^{-1}$ \\
\hline$\theta_{\text {bact }}$ & Bacterial nitrogen biomass growth & $\mathrm{mmol} \mathrm{m}{ }^{-3} \mathrm{~h}^{-1}$ \\
\hline$\eta_{\text {bact }_{\text {[CN.P] }}}$ & Bacterial mortality & $\mathrm{mmol} \mathrm{m} \mathrm{m}^{-3} \mathrm{~h}^{-1}$ \\
\hline$\delta_{D O M_{[, N . P}}$ & $D O M_{\mathrm{SL}}$ hydrolysis & $\mathrm{mmol} \mathrm{m} \mathrm{m}^{-3} \mathrm{~h}^{-1}$ \\
\hline$\delta_{\mathrm{CO}_{2}}$ & $\mathrm{CO}_{2}$ air-water interface diffusion & $\mathrm{mmol} \mathrm{m}{ }^{-3} h^{-1}$ \\
\hline$\delta_{\mathrm{O}_{2}}$ & $\mathrm{O}_{2}$ air-water interface diffusion & $\mathrm{mmol} \mathrm{m}^{-3} \mathrm{~h}^{-1}$ \\
\hline
\end{tabular}

Table 4

The biogeochemical model state equations.

$$
\begin{aligned}
& \frac{d E h_{\mathrm{C}}}{d t}=\mu_{\mathrm{C}}-\rho_{\mathrm{Eh}}-\pi_{\mathrm{Eh}_{\mathrm{C}}}-\eta_{\mathrm{Eh}_{\mathrm{C}}}-\sigma_{\mathrm{Eh}_{\mathrm{C}}} \\
& \frac{d E h_{\mathrm{N}}}{d t}=\mu_{\mathrm{NO}_{x}}+\mu_{\mathrm{NH}_{x}}-\pi_{\mathrm{Eh}_{\mathrm{N}}}-\eta_{\mathrm{Eh}_{\mathrm{N}}}-\sigma_{\mathrm{Eh}_{\mathrm{N}}} \\
& \frac{d B a c t_{\mathrm{N}}}{d t}=\theta_{\mathrm{bact}}-\eta_{\mathrm{bact}_{\mathrm{N}}} \\
& \frac{d E h V}{d t}=\left(\eta_{\mathrm{vir}} V_{\mathrm{b}} E h_{\mathrm{C}}\right)-\left(E h V V_{\mathrm{d}} Q_{\mathrm{T}}\right) \\
& \frac{d P C H O}{d t}=\tau_{\mathrm{ee}}\left(1-L_{\tau_{\mathrm{ee}}}\right)-\left(\alpha_{\mathrm{PCHO}} P C H O P C H O\right)-\left(\beta_{\mathrm{PCHO}} P_{C H O T E P_{\mathrm{C}}}\right) \\
& \frac{d T E P_{\mathrm{C}}}{d t}=\left(\alpha_{\mathrm{PCHO}} P C H O P C H O\right)+\left(\beta_{\mathrm{PCHO}} \text { PCHOTEP }\right)-\sigma_{\mathrm{TEP}} \\
& \frac{d N O_{x}}{d t}=\delta_{\mathrm{NH}_{x}}-\mu_{\mathrm{NO}_{x}} \\
& \frac{d N H_{x}}{d t}=\varepsilon_{N H_{x}}-\mu_{\mathrm{NH}_{x}}-\delta_{N H_{x}}
\end{aligned}
$$


Table 4 (continued)

$$
\begin{aligned}
& \frac{d P O_{4}}{d t}=\varepsilon_{P O_{4}}-\mu_{P_{4}} \\
& \frac{d D I C}{d t}=\rho_{\text {Eh }}-\mu_{\mathrm{C}}-\tau_{\text {calc }}+\tau_{\text {dissol }}-\tau_{\text {ee }}+\rho_{\text {bact }}+\delta_{\mathrm{CO}_{2}} \\
& \frac{d D O}{d t}=R_{\mathrm{ON}}\left(\mu_{\mathrm{NO}_{x}}-\delta_{\mathrm{NH}_{x}}\right)+R_{\mathrm{OC}}\left(\mu_{\mathrm{C}}-\rho_{\mathrm{Eh}}+\tau_{\mathrm{ee}}-\rho_{\mathrm{bact}}\right)+\delta_{\mathrm{O}_{2}} \\
& \frac{d T A}{d t}=2\left(\tau_{\text {dissol }}-\tau_{\text {calc }}\right) \\
& \frac{d D O C_{\mathrm{L}}}{d t}=\pi_{\mathrm{Eh}_{\mathrm{C}}}+\tau_{\mathrm{ee}} L_{\tau_{\mathrm{ee}}}+\delta_{\mathrm{DOM}_{\mathrm{C}}}+\eta_{\mathrm{Eh}_{\mathrm{C}}} D_{\eta_{\mathrm{Eh}}} P_{\mathrm{Sll}}\left(1-P_{\mathrm{ref}}\right) \\
& +\delta_{\text {det }_{\mathrm{C}}} P_{\text {sll }}\left(1-P_{\text {ref }}\right)-v_{\text {DOM }_{\mathrm{c}}}+\eta_{\text {bact }_{\mathrm{C}}} F_{\text {bd }} F_{\mathrm{bl}}\left(1-P_{\text {ref }}\right) \\
& \frac{d D O C_{\mathrm{SL}}}{d t}=\eta_{E h_{\mathrm{C}}} D_{\eta_{\mathrm{Eh}_{\mathrm{C}}}}\left(1-P_{\mathrm{Sll}}\right)\left(1-P_{\mathrm{ref}}\right)+\delta_{\operatorname{det}_{\mathrm{C}}}\left(1-P_{\mathrm{sll}}\right)\left(1-P_{\text {ref }}\right) \\
& +\eta_{\text {bact }_{\mathrm{c}}} F_{\text {bd }}\left(1-F_{\mathrm{bl}}\right)\left(1-P_{\text {ref }}\right)-\delta_{\text {DoM }_{\mathrm{c}}} \\
& \frac{d D O N_{\mathrm{L}}}{d t}=\pi_{E h_{\mathrm{N}}}+\delta_{D O M_{\mathrm{N}}}+\eta_{E h_{\mathrm{N}}} D_{\eta_{E h_{\mathrm{N}}}} P_{\mathrm{Sll}}\left(1-P_{\text {ref }}\right) \\
& +\delta_{\text {det }_{\mathrm{N}}} P_{\text {sll }}\left(1-P_{\text {ref }}\right)-v_{\text {DoM }_{\mathrm{N}}}+\eta_{\text {bact }_{\mathrm{N}}} F_{\mathrm{bd}} F_{\mathrm{bl}}\left(1-P_{\text {ref }}\right) \\
& \frac{d D O N_{S L}}{d t}=\eta_{E h_{N}} D_{\eta_{E h_{N}}}\left(1-P_{\text {Sll }}\right)\left(1-P_{\text {ref }}\right)+\delta_{\operatorname{det}_{N}}\left(1-P_{\text {sll }}\right)\left(1-P_{\text {ref }}\right) \\
& +\eta_{\text {bact }_{\mathrm{N}}} F_{\mathrm{bd}}\left(1-F_{\mathrm{bl}}\right)\left(1-P_{\text {ref }}\right)-\delta_{\text {DoM }_{\mathrm{N}}} \\
& \frac{d D O P_{\mathrm{L}}}{d t}=\pi_{E h_{\mathrm{P}}}+\delta_{D O M_{\mathrm{P}}}+\eta_{E h_{\mathrm{p}}} D_{\eta_{\mathrm{Eh}}} P_{\mathrm{SIl}}\left(1-P_{\mathrm{ref}}\right)-\mu_{\mathrm{DOP}} \\
& +\delta_{\operatorname{det}_{\mathrm{p}}} P_{\text {sll }}\left(1-P_{\text {ref }}\right)-v_{\text {DOM }}+\eta_{\text {bact }} F_{\text {bd }} F_{\mathrm{bl}}\left(1-P_{\text {ref }}\right) \\
& \frac{d D O P_{\mathrm{SL}}}{d t}=\eta_{E h_{\mathrm{p}}} D_{\eta_{\mathrm{Ehp}}}\left(1-P_{\text {SIII }}\right)\left(1-P_{\text {ref }}\right)+\delta_{\operatorname{det}_{\mathrm{p}}}\left(1-P_{\mathrm{SIl}}\right)\left(1-P_{\text {ref }}\right) \\
& +\eta_{\text {bact }} F_{\mathrm{bd}}\left(1-F_{\mathrm{bl}}\right)\left(1-P_{\text {ref }}\right)-\delta_{\text {DOM }_{\mathrm{p}}}-\mu_{\text {DOPsl }} \\
& \frac{d E h_{\text {calc }}}{d t}=\tau_{\text {calc }}-\tau_{\text {detach }}-\eta_{E h_{\text {calc }}}-\sigma_{E h_{\text {calc }}} \\
& \frac{d D e t_{\text {calc }}}{d t}=\tau_{\text {detach }}-\tau_{\text {dissol }}+\eta_{E_{\text {calc }}}-\sigma_{D t_{\text {calc }}}
\end{aligned}
$$

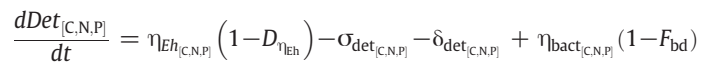

Table 5

Mathematical formulation of biogeochemical fluxes.



$$
\begin{aligned}
& \text { Chla }=N C_{\min }\left(N C h l_{\min }+\left(N C h l_{\max }-N C h l_{\min }\right) \frac{N C-N C_{\min }}{N C_{\max }-N C_{\max }}\right) E h_{\mathrm{C}} \\
& E h_{\mathrm{P}}=E h_{\mathrm{N}} P N \\
& \text { Phytoplankton nutrients uptake } \\
& \mu_{\mathrm{C}}=R_{\mu_{\mathrm{C}}} \frac{\lambda}{\lambda+K_{\lambda}} \frac{D I C}{D I C+K_{\mathrm{DIC}}}\left(1-\frac{N C_{\min }}{N C}\right) E h_{\mathrm{C}} Q_{T_{\mathrm{Eh}}} \\
& \rho_{\mathrm{Eh}}=R_{\rho_{\mathrm{Eh}}} E h_{\mathrm{C}}+F_{\rho_{\mathrm{En}}} \mu_{\mathrm{C}} \\
& p o t \mu_{\mathrm{NO}_{x}}=R_{\mu_{\mathrm{NO}_{x}}} \frac{N O_{x}}{N O_{x}+K_{N O_{x}}}\left(1-\frac{N H_{x}}{N H_{x}+K i_{N H_{x}}}\right)\left(1-\frac{N C}{N C_{\max }}\right) E h_{\mathrm{C}} Q_{T_{\mathrm{Eh}}}
\end{aligned}
$$

Table 5 (continued)

$$
\begin{aligned}
& \operatorname{pot}_{\mathrm{NH}_{x}}=R_{\mu_{\mathrm{NH}}} \frac{N H_{x}}{N H_{x}+K_{N H_{x}}}\left(1-\frac{N C}{N C_{\max }}\right) E h_{C} Q_{T_{E h}} \\
& \text { pot } \mu_{\mathrm{PO}_{4}}=R_{\mu_{\mathrm{po}_{4}}} \frac{\mathrm{PO}_{4}}{\mathrm{PO}_{4}+K_{\mathrm{PO}_{4}}} E h_{\mathrm{C}} Q_{T_{\mathrm{Eh}}} \\
& \operatorname{pot}_{\mathrm{DOP}}=R_{\mu_{\mathrm{LOP}} \mathrm{OP}} \frac{D O P_{\mathrm{L}}+D O P_{\mathrm{SL}}}{D O P_{\mathrm{L}}+D O P_{\mathrm{SL}}+K_{\mathrm{DOP}}}\left(1-\frac{P O_{4}}{P O_{4}+K i_{\mathrm{PO}_{4}}}\right) \frac{D O P_{[\mathrm{LSL}]}}{D O P_{\mathrm{L}}+D O P_{\mathrm{SL}}} E h_{\mathrm{C}} Q_{T_{\mathrm{EL}}} \\
& \text { For }\left(p o t \mu_{\mathrm{NO}_{x}}+p o t \mu_{\mathrm{NH}_{x}}\right)<\frac{\left(p o t \mu_{\mathrm{PO}_{4}}+p o t \mu_{D O P_{\mathrm{L}}}+p o t \mu_{D O P_{S L}}\right)}{P N} \\
& \mu_{\mathrm{PO}_{4}}=\left(\operatorname{pot} \mu_{\mathrm{NO}_{x}}+\operatorname{pot}_{\mathrm{NH}_{x}}\right) P N \frac{p o t \mu_{\mathrm{PO}_{4}}}{\operatorname{pot}_{\mathrm{PO}_{4}}+\operatorname{pot} \mu_{\mathrm{DOP}_{\mathrm{L}}}+\operatorname{pot} \mu_{\mathrm{DOP}}}
\end{aligned}
$$

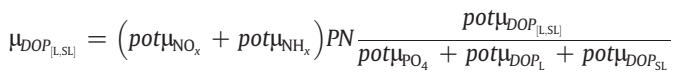

$$
\begin{aligned}
& \operatorname{For}\left(p o t \mu_{\mathrm{NO}_{x}}+p o t \mu_{\mathrm{NH}_{x}}\right)>\frac{\left(p o t \mu_{\mathrm{PO}_{4}}+\operatorname{pot}_{\mathrm{DOP}_{\mathrm{L}}}+\operatorname{pot}_{\mathrm{DOP}}\right)}{P N} \\
& \mu_{\mathrm{NO}_{x}}=\frac{\operatorname{pot}_{\mathrm{PO}_{4}}+\operatorname{pot} \mu_{D O P_{\mathrm{L}}}+p o t \mu_{D O P_{\mathrm{SL}}}}{P N} \frac{p o t \mu_{\mathrm{NO}_{x}}}{\operatorname{pot} \mu_{\mathrm{NO}_{x}}+\operatorname{pot} \mu_{\mathrm{NH}_{x}}} \\
& \mu_{\mathrm{NH}_{x}}=\frac{p o t \mu_{\mathrm{PO}_{4}}+p o t \mu_{\mathrm{DOP}}+\operatorname{pot}_{\mathrm{DOP}}}{P N} \frac{p o t \mu_{\mathrm{NH}_{x}}}{\operatorname{pot}_{\mathrm{NO}_{x}}+p o t \mu_{\mathrm{NH}_{x}}}
\end{aligned}
$$

Phytoplankton passive leakage and extra - excretion

$\pi_{\mathrm{Eh}_{\mathrm{c}}}=F_{\pi} \mu_{\mathrm{C}}$

$\Pi_{\mathrm{Eh}_{\mathrm{N}}}=F_{\pi} \max \left[0 ;\left(\mu_{\mathrm{NO}_{x}}+\mu_{\mathrm{NH}_{x}}\right)\right]$

$\pi_{\mathrm{Eh}_{\mathrm{p}}}=\pi_{\mathrm{Eh}_{\mathrm{N}}} P N$

$\tau_{\mathrm{ee}}=\gamma_{\mathrm{ee}} \frac{\lambda}{\lambda+K_{\lambda}} \frac{D I C}{D I C+K_{D I C}} \tau_{\text {calc }} Q_{T_{\mathrm{Eh}}}$

Phytoplankton calcification, coccoliths detachment and calcite dissolution

$$
\begin{aligned}
& \tau_{\text {calc }}=R_{\text {calc }} E h_{\mathrm{C}}+F_{\text {Calc }} \max \left[0 ; \mu_{\mathrm{C}}-\rho_{\text {Eh }}\right] \max \left[0 ; 1-\frac{N C}{N C_{\text {max }}}\right] \\
& \tau_{\text {detach }}=R_{\text {det }} E h_{\text {calc }}+\max \left[0 ; R_{\text {det }_{\text {max }}}\left(E h_{\text {calc }}-C C_{\max } C C_{\mathrm{c}} \frac{E h_{\mathrm{C}}}{E h_{\text {cont }}}\right)\right] \\
& \tau_{\text {dissol }}=R_{\text {diss }} D e t_{\text {calc }}\left(1-\Omega_{\text {calc }}^{\omega}\right) Q_{T_{\text {calc }}} \\
& \Omega_{\text {calc }}=\frac{0.01028 \frac{S}{35} C O_{3}}{K_{\text {calcite }} 1 \mathrm{e} 6}
\end{aligned}
$$

Virus dynamics

$$
\begin{aligned}
& \text { prox }=\left(E h V \frac{E h_{\mathrm{C}}}{E h_{\mathrm{C}_{\text {cont }}}}\right)^{0.5} \\
& R_{\eta_{\text {vir }}}=\eta_{\text {vir }_{\text {max }}}\left(\tanh \left[\sigma\left(\frac{\operatorname{prox}}{\operatorname{th} h_{\text {EhV }}}-1\right)\right]-\tanh [-\sigma]\right)(1-\tanh [-\sigma])^{-1}
\end{aligned}
$$

Phytoplankton mortality

$$
\begin{aligned}
& \eta_{E h_{[, N]}}=E h_{[C, N]}\left(Q_{T_{E h}} R_{\eta}+R_{\eta_{\text {vir }}}\right) \\
& \eta_{E h_{\mathrm{P}}}=\eta_{E h_{N}} P N
\end{aligned}
$$


Table 5 (continued)

$\eta_{E h_{\text {calc }}}=E h_{\text {calc }}\left(Q_{T_{\mathrm{Eh}}} R_{\eta}+R_{\eta_{\text {vir }}}\right)$

Phytoplankton, freecalcite, TEP and detritus sedimentation

$\sigma_{E h_{[\mathrm{C}, \mathrm{N}, \mathrm{calc}]}}=E h_{[\mathrm{C}, \mathrm{N}, \mathrm{calc}]} \frac{E h_{\mathrm{ss}}}{d e p t h}$

$\sigma_{\text {det }_{\text {calc }}}=\operatorname{Det}_{\text {calc }} \frac{\operatorname{Det}_{\mathrm{calc}_{\mathrm{ss}}}}{\text { depth }}$

$\sigma_{\mathrm{TEP}}=T E P_{\mathrm{C}} \frac{T E P_{\mathrm{C}_{\mathrm{ss}}}}{\operatorname{depth}}$

$\sigma_{\operatorname{det}_{[\mathrm{C}, \mathrm{N}, \mathrm{P}]}}=\operatorname{Det}_{[\mathrm{C}, \mathrm{N}, \mathrm{P}]} \frac{\operatorname{Det}_{\mathrm{ss}}}{\operatorname{depth}}$

Regeneration and microbial loop

$\delta_{\operatorname{det}_{C_{C, N . P]}}}=R_{\delta_{\text {C.N.P. }}} Q_{T_{\mathrm{Eh}}} \operatorname{Det}_{[\mathrm{C}, \mathrm{N}, \mathrm{P}]}$

$\delta_{\mathrm{NH}_{x}}=R_{\mathrm{nit}} \frac{D O}{D O+K_{\mathrm{DO}}} Q_{T_{\text {nit }}} N H_{x}$

Bact $_{\mathrm{C}}=\frac{\text { Bact }_{\mathrm{N}}}{N C_{\text {bact }}}$

Bact $_{\mathrm{P}}=$ Bact $_{\mathrm{N}} P N_{\text {bact }}$

$v_{D^{\prime O M}}=R_{v_{\mathrm{C}}}$ Bact $_{\mathrm{C}} \frac{D O C_{\mathrm{L}}}{D O C_{\mathrm{L}}+K_{\mathrm{DOC}}} Q_{T_{\text {bact }}}$

$v_{D O M_{\mathrm{N}}}=v_{D O M_{\mathrm{C}}} \frac{D O N_{\mathrm{L}}}{D O C_{\mathrm{L}}}$

$v_{\mathrm{DOM}_{\mathrm{P}}}=v_{\mathrm{DOM}_{\mathrm{C}}} \frac{D O P_{\mathrm{L}}}{D O C_{\mathrm{L}}}$

$\rho_{\text {bact }}=v_{D O M_{C}}(1-\varepsilon)$

$v_{\mathrm{NH}_{x}}=R_{v_{\mathrm{NH}_{x}}}$ Bact $_{\mathrm{N}} \frac{N H_{x}}{N H_{x}+K_{\text {bact }_{\mathrm{NH}_{x}}}} Q_{T_{\text {bact }}}$

$v_{\mathrm{PO}_{4}}=R_{v_{\mathrm{PO}_{4}}}$ Bact $_{\mathrm{P}} \frac{\mathrm{PO}_{4}}{\mathrm{PO}_{4}+K_{\text {bact }_{\mathrm{PO}_{4}}}} Q_{\mathrm{b}_{\text {bact }}}$

$\delta_{\mathrm{DOM}_{[\mathrm{C}, \mathrm{N}, \mathrm{P}]}}=R_{\delta_{\text {bact }}} \operatorname{Bact}_{\mathrm{C}} \frac{\mathrm{DOM}_{[\mathrm{C}, \mathrm{N}, \mathrm{P}]}}{\operatorname{DOM}_{[\mathrm{C}, \mathrm{N}, \mathrm{P}]}+K_{\left.\delta_{\text {DOM }}, \mathrm{C}, \mathrm{N}, \mathrm{P}\right]}}$

$\eta_{\text {bact } \text { [CN,P] }}=R_{\eta_{\text {bact }}}$ Bact $_{[\mathrm{C}, \mathrm{N}, \mathrm{P}]} Q_{T_{\text {bact }}}$

Table 6

Parameters values for biological processes.

\begin{tabular}{|c|c|c|c|c|}
\hline Par. & Units & Value & Description & Ref. \\
\hline$Q 10_{E h}$ & - & 1.5 & Ehux. Q10 & (6) \\
\hline$R_{\mu_{\mathrm{c}}}$ & $h^{-1}$ & 0.11 & $\begin{array}{l}\text { Ehux. maximal } \\
\text { growth rate }\end{array}$ & $\begin{array}{l}\text { Adapt. } \\
\text { from (5) }\end{array}$ \\
\hline$K_{\lambda}$ & $\begin{array}{l}\mu \mathrm{mol} \\
\mathrm{m}^{-2} \mathrm{~s}^{-1}\end{array}$ & 20 & PAR half-sat. & (c) \\
\hline$K_{\text {DIC }}$ & $\mathrm{mmol} \mathrm{m}^{-3}$ & 150 & DIC half-sat. & (c) \\
\hline PN & $\mathrm{mol} \mathrm{mol}^{-1}$ & $4.2 \cdot 10^{-2}$ & Ehux. P:N ratio & (5) \\
\hline$N C_{\min }$ & $\mathrm{mol} \mathrm{mol}^{-1}$ & $5.0 \cdot 10^{-2}$ & Ehux. min. $\mathrm{N}: \mathrm{C}$ ratio & (2) \\
\hline$N C_{\max }$ & $\mathrm{mol} \mathrm{mol}^{-1}$ & 0.2 & Ehux. max. N:C ratio & (2) \\
\hline
\end{tabular}

Table 6 (continued)

\begin{tabular}{|c|c|c|c|c|}
\hline Par. & Units & Value & Description & Ref. \\
\hline$N C h l_{\text {min }}$ & $\mathrm{mg} \mathrm{mol}^{-1}$ & 0.15 & $\begin{array}{l}\text { Ehux. min. chla: } \\
\mathrm{N} \text { ratio }\end{array}$ & $(2)$ \\
\hline$N C h l_{\max }$ & $\mathrm{mg} \mathrm{mol}^{-1}$ & 1.2 & Ehux. max. chla:N ratio & $(2)$ \\
\hline$R_{\rho_{\mathrm{Eh}}}$ & $h^{-1}$ & $3.0 \cdot 10^{-3}$ & $\begin{array}{l}\text { Ehux. basal } \\
\text { respiration rate }\end{array}$ & $\begin{array}{l}\text { Adapt. from } \\
\text { (2) }\end{array}$ \\
\hline$F_{\rho_{\text {Eh }}}$ & - & 0.1 & $\begin{array}{l}\text { Fract. of production } \\
\text { that is respired }\end{array}$ & $(2)$ \\
\hline$K_{\mathrm{NO}_{x}}$ & $\mathrm{mmol} \mathrm{m}^{-3}$ & 1.5 & $\mathrm{NO}_{x}$ half-sat. & $(2)$ \\
\hline$K i_{\mathrm{NH}_{x}}$ & $\mathrm{mmol} \mathrm{m}^{-3}$ & $1.0 \cdot 10^{-2}$ & $\begin{array}{l}\mathrm{NH}_{x} \text { half-sat. } \\
\text { inhibiting } \mathrm{NO}_{x}\end{array}$ & (c) \\
\hline$R_{\mu_{\mathrm{NOx}}}$ & $\begin{array}{l}\mathrm{mol} \\
\mathrm{mol}^{-1} \\
\mathrm{~h}^{-1}\end{array}$ & 0.2 & $\begin{array}{l}\text { Ehux. } \mathrm{NO}_{x} \text { uptake } \\
\text { rate }\end{array}$ & (c) \\
\hline$K_{\mathrm{NH}_{x}}$ & $\mathrm{mmol} \mathrm{m}^{-3}$ & 0.1 & $\mathrm{NH}_{X}$ half-sat. & $(2)$ \\
\hline$R_{\mu_{\mathrm{NHx}}}$ & $\begin{array}{l}\mathrm{mol} \mathrm{mol}^{-1} \\
\mathrm{~h}^{-1}\end{array}$ & $5.0 \cdot 10^{-2}$ & $\begin{array}{l}\text { Ehux. } \mathrm{NH}_{x} \text { uptake } \\
\text { rate }\end{array}$ & (2) \\
\hline$K_{\mathrm{PO}_{4}}$ & $\mathrm{mmol} \mathrm{m}^{-3}$ & $5.0 \cdot 10^{-2}$ & $\mathrm{PO}_{4}$ half-sat. & (c) \\
\hline $\mathrm{Ki}_{\mathrm{PO}_{4}}$ & $\mathrm{mmol} \mathrm{m}^{-3}$ & 0.5 & $\begin{array}{l}\mathrm{PO}_{4} \text { half-sat. } \\
\text { inhibiting DOP }\end{array}$ & (c) \\
\hline$R_{\mu_{\mathrm{PO} 4}}$ & $\begin{array}{l}\mathrm{mol} \mathrm{mol}^{-1} \\
\mathrm{~h}^{-1}\end{array}$ & $5.0 \cdot 10^{-2}$ & Ehux. $\mathrm{PO}_{4}$ uptake rate & (c) \\
\hline$K_{D O P}$ & $\mathrm{mmol} \mathrm{m}^{-3}$ & $1.5 \cdot 10^{-2}$ & DOP half-sat. & (c) \\
\hline$R_{\mu_{D O P}}$ & $\begin{array}{l}\mathrm{mol} \mathrm{mol} \\
\mathrm{h}^{-1}\end{array}$ & $1.0 \cdot 10^{-2}$ & $\begin{array}{l}\text { Ehux. DOP uptake } \\
\text { rate }\end{array}$ & (c) \\
\hline$F_{\pi}$ & - & $2.0 \cdot 10^{-2}$ & Ehux. passive leakage & (3) \\
\hline$R_{\text {calc }}$ & $\mathrm{h}^{-1}$ & $1.0 \cdot 10^{-3}$ & $\begin{array}{l}\text { Ehux. permanent } \\
\text { calcif. rate }\end{array}$ & $\begin{array}{l}\text { Adapt. from } \\
\text { (7) }\end{array}$ \\
\hline$F_{\text {Ccalc }}$ & - & 1.9 & $\begin{array}{l}\text { Ehux. calcite : } C_{\text {organic }} \\
\text { growth ratio }\end{array}$ & (c) \\
\hline$E h_{\mathrm{C}_{\text {cont }}}$ & $\begin{array}{l}\mathrm{mmol} \\
\text { cell }^{-1}\end{array}$ & $2.0 \cdot 10^{-9}$ & $\begin{array}{l}\mathrm{C}_{\text {organic }} \text { content of } \\
\text { Ehux. cell }\end{array}$ & $\begin{array}{l}\text { Calc. from } \\
\text { data }\end{array}$ \\
\hline$C C_{\mathrm{c}}$ & $\begin{array}{l}\text { mmol } \\
\text { ccolith }^{-1}\end{array}$ & $1.0 \cdot 10^{-10}$ & $\begin{array}{l}\text { Calcite content of } \\
\text { coccolith }\end{array}$ & $(5)$ \\
\hline$C C_{\max }$ & $\begin{array}{l}\text { ccolith } \\
\text { cell }^{-1}\end{array}$ & 15.0 & $\begin{array}{l}\text { Max. coccoliths } \\
\text { attached on cell surface }\end{array}$ & (7) \\
\hline$R_{\text {det }_{\max }}$ & $\mathrm{h}^{-1}$ & 0.45 & $\begin{array}{l}\text { Detachment rate of } \\
\text { excess coccoliths }\end{array}$ & $(2)$ \\
\hline$R_{\text {det }}$ & $\mathrm{h}^{-1}$ & $1.0 \cdot 10^{-3}$ & $\begin{array}{l}\text { Basal detachment } \\
\text { rate of coccoliths }\end{array}$ & $(2)$ \\
\hline$R_{\mathrm{diss}}$ & $\mathrm{h}^{-1}$ & 0.21 & $\begin{array}{l}\text { Kinetic rate for calcite } \\
\text { dissolution }\end{array}$ & $\begin{array}{l}\text { From Keir } \\
(1980)\end{array}$ \\
\hline$\omega$ & - & 4.5 & $\begin{array}{l}\text { Order of calcite } \\
\text { dissolution }\end{array}$ & $\begin{array}{l}\text { From Keir } \\
(1980)\end{array}$ \\
\hline Q10 calc & - & 1.3 & $\begin{array}{l}\mathrm{CaCO}_{3} \text { dissolution } \\
\text { Q10 }\end{array}$ & $\begin{array}{l}\text { From Morse and } \\
\text { Arvidson (2002) }\end{array}$ \\
\hline$\gamma_{\mathrm{ee}}$ & - & 0.8 & $\begin{array}{l}\text { Fract. of calcif. linked } \\
\text { to DOC extra-excr. }\end{array}$ & $\begin{array}{l}\text { Adapt. } \\
\text { from (3) }\end{array}$ \\
\hline$P_{\text {sll }}$ & - & 0.13 & $\begin{array}{l}\mathrm{DOM}_{\mathrm{L}} \text { fract. from } \\
\eta_{\text {Eh }} \text { and } \eta_{\text {Det }}\end{array}$ & (c) \\
\hline$D_{\eta_{\mathrm{Eh}}}$ & - & 0.34 & $\begin{array}{l}\text { DOM fract. of Ehux. } \\
\text { mortality }\end{array}$ & $(1)$ \\
\hline$P_{\text {ref }}$ & - & 0.5 & $\begin{array}{l}\text { Part. } \text { DOM }_{\text {refract }} \text { and } \\
\text { DOM }_{\text {non-refract }}\end{array}$ & (c) \\
\hline$L_{\tau_{\mathrm{ee}}}$ & - & 0.1 & $\begin{array}{l}\text { Fract. of } \mathrm{DOM}_{\mathrm{L}} \text { in } \mathrm{DOC} \\
\text { extra excretion }\end{array}$ & $(8)$ \\
\hline$\alpha_{P C H O}$ & - & $3.12 \cdot 10^{-5}$ & Coagulation coef. of $\mathrm{PCHO}$ & $(8)$ \\
\hline$\beta_{P C H O}$ & - & $1.07 \cdot 10^{-3}$ & $\begin{array}{l}\text { Adsorption coef. between } \\
\text { PCHO and } \mathrm{TEP}_{\mathrm{C}}\end{array}$ & $(8)$ \\
\hline$\eta_{\text {vir }_{\max }}$ & $\mathrm{h}^{-1}$ & $2.0 \cdot 10^{-2}$ & $\begin{array}{l}\text { Max. mortality rate } \\
\text { by viral lysis }\end{array}$ & (c) \\
\hline$t h_{\mathrm{EhV}}$ & part $\mathrm{m}^{-3}$ & $0.5 \cdot 10^{12}$ & $\begin{array}{l}\text { Threshold virus-cells } \\
\text { proximity }\end{array}$ & (c) \\
\hline$\sigma$ & - & 2.0 & $\begin{array}{l}\text { Slope characterising } \\
\text { viral mortality rate }\end{array}$ & (c) \\
\hline$V_{\mathrm{d}}$ & $h^{-1}$ & $1.55 \cdot 10^{-2}$ & Virus degeneracy rate & (c) \\
\hline$V_{\mathrm{b}}$ & part $\mathrm{mmol}^{-1}$ & $5.5 \cdot 10^{11}$ & Viral spread-out coef. & $\begin{array}{l}\text { From Jacquet } \\
\text { et al. (2002) }\end{array}$ \\
\hline$R_{\eta}$ & $\mathrm{h}^{-1}$ & $3.0 \cdot 10^{-3}$ & $\begin{array}{l}\text { Non-viral Ehux. } \\
\text { mortality rate }\end{array}$ & (c) \\
\hline $\operatorname{Det}_{\mathrm{calc}_{\mathrm{ss}}}$ & $\mathrm{m} \mathrm{h}^{-1}$ & $2.0 \cdot 10^{-2}$ & Calcite sinking speed & (5) \\
\hline$E h_{\mathrm{ss}}$ & $\mathrm{m} \mathrm{h}^{-1}$ & $1.5 \cdot 10^{-2}$ & Ehux. sinking speed & (5) \\
\hline $\operatorname{Det}_{\mathrm{ss}}$ & $\mathrm{m} \mathrm{h}^{-1}$ & $4.0 \cdot 10^{-2}$ & Detritus sinking speed & $\begin{array}{l}\text { Calc. from } \\
\text { data }\end{array}$ \\
\hline$T E P_{\mathrm{C}_{\mathrm{ss}}}$ & $\mathrm{m} \mathrm{h}^{-1}$ & $2.0 \cdot 10^{-3}$ & $\mathrm{TEP}_{\mathrm{C}}$ sinking speed & $\begin{array}{l}\text { Calc. from } \\
\text { data }\end{array}$ \\
\hline depth & $\mathrm{m}$ & 4.5 & $\begin{array}{l}\text { Depth of mesocosm } \\
\text { water column }\end{array}$ & From data \\
\hline
\end{tabular}


Table 6 (continued)

\begin{tabular}{|c|c|c|c|c|}
\hline Par. & Units & Value & Description & Ref. \\
\hline$R_{\delta_{\mathrm{c}}}$ & $\mathrm{h}^{-1}$ & $1.88 \cdot 10^{-3}$ & $\begin{array}{l}\text { Detritus carbon } \\
\text { decay rate }\end{array}$ & (4) \\
\hline$R_{\delta_{\mathrm{N}}}$ & $h^{-1}$ & $2.29 \cdot 10^{-3}$ & $\begin{array}{l}\text { Detritus nitrogen } \\
\text { decay rate }\end{array}$ & (4) \\
\hline$R_{\delta_{\mathrm{p}}}$ & $h^{-1}$ & $2.71 \cdot 10^{-3}$ & $\begin{array}{l}\text { Detritus phosphorus } \\
\text { decay rate }\end{array}$ & (4) \\
\hline$R_{\text {nit }}$ & $\mathrm{h}^{-1}$ & $2.1 \cdot 10^{-3}$ & $\begin{array}{l}\mathrm{NH}_{4}^{+} \text {oxidation rate } \\
\text { at } 20 \mathrm{dg}\end{array}$ & (1) \\
\hline$K_{\mathrm{DO}}$ & $\mathrm{mmol} \mathrm{m}^{-3}$ & 1.0 & $\begin{array}{l}\text { DO half-saturation } \\
\text { for nitrification }\end{array}$ & (1) \\
\hline Q10 ${ }_{\text {nit }}$ & - & 2.0 & Nitrification Q10 & (1) \\
\hline$R_{\mathrm{ON}}$ & $\mathrm{mol} \mathrm{mol}^{-1}$ & 2.0 & $\begin{array}{l}\text { DO stoechiometry } \\
\text { for nitrification }\end{array}$ & $(-)$ \\
\hline$R_{\mathrm{OC}}$ & $\mathrm{mol} \mathrm{mol}^{-1}$ & 1.0 & $\begin{array}{l}\text { DO stoechiometry } \\
\text { for biosynthesis }\end{array}$ & $(-)$ \\
\hline$N C_{\text {bact }}$ & $\mathrm{mol} \mathrm{mol}^{-1}$ & 0.25 & Bact. $\mathrm{N}: \mathrm{C}$ ratio & (1) \\
\hline$P N_{\text {bact }}$ & $\mathrm{mol} \mathrm{mol}^{-1}$ & 0.1 & Bact. P:N ratio & (1) \\
\hline Q10 ${ }_{\text {Bact }}$ & - & 2.0 & Bact. Q10 & (1) \\
\hline$R_{\nu_{c}}$ & $\mathrm{~h}^{-1}$ & 0.417 & Bact. $\mathrm{DOC}_{\mathrm{L}}$ uptake rate & (1) \\
\hline$K_{\mathrm{DOC}_{\mathrm{L}}}$ & $\mathrm{mmol} \mathrm{m}^{-3}$ & 25.0 & Bact. $\mathrm{DOC}_{\mathrm{L}}$ half-sat. & (1) \\
\hline$K_{\text {bact }_{\mathrm{NH} x}}$ & $\mathrm{mmol} \mathrm{m}^{-3}$ & 0.5 & Bact. $\mathrm{NH}_{x}$ half-sat. & (1) \\
\hline$K_{\text {bact }_{\mathrm{PO} 4}}$ & $\mathrm{mmol} \mathrm{m}^{-3}$ & 0.01 & Bact. $\mathrm{PO}_{4}$ half-sat. & (1) \\
\hline$F_{\mathrm{bd}}$ & - & 0.51 & $\begin{array}{l}\text { Frac. of bact. mortality } \\
\text { consisting of DOM }\end{array}$ & (1) \\
\hline$F_{\mathrm{bl}}$ & - & 0.1 & $\begin{array}{l}\text { Fract. of bact. } \\
\text { DOM }_{\text {non-refrac }} \\
\text { devoted to } \mathrm{DOM}_{\mathrm{L}}\end{array}$ & (1) \\
\hline$R_{\eta_{\text {bact }}}$ & $h^{-1}$ & $8.1 \cdot 10^{-3}$ & Bact. mortality rate & (1) \\
\hline$\varepsilon$ & - & 0.27 & Bact. growth efficiency & (1) \\
\hline$R_{\delta_{\text {bact }}}$ & $\mathrm{h}^{-1}$ & 0.167 & $\begin{array}{l}\text { Bact. hydrolysis } \\
\mathrm{DOC}_{\mathrm{SL}} \text { rate }\end{array}$ & (1) \\
\hline$K_{\delta_{\text {DOM[CN,P] }}}$ & $\mathrm{mmol} \mathrm{m}^{-3}$ & 417 & $\begin{array}{l}\text { Bact. hydrolysis } \\
\text { DOC }_{S L} \text { half-sat. }\end{array}$ & (1) \\
\hline
\end{tabular}

(c) After calibration. References: (1)Anderson and Pondaven (2003), (2)Tyrrell and Taylor (1996), (3) Van Den Meersche et al. (2004), (4) Lancelot et al. (2002), (5) Paasche (2002), (6) Oguz and Merico (2006), (7)Merico et al. (2004), (8) Engel et al. (2004a,b).

\section{References}

Aksnes, D., Egge, J., Rosland, R., Heimdal, B., 1994. Representation of Emiliania huxleyi in phytoplankton simulation models. A first approach. Sarsia 79, 291-300.

Anderson, T., Pondaven, P., 2003. Non-Redfield carbon and nitrogen cycling in the Sargasso Sea: pelagic imbalances and export flux. Deep-Sea Research Part I 50, 573-591.

Anderson, L., Sarmiento, J., 1994. Redfield ratios of remineralization determined by nutrient data analysis. Global Biogeochemical Cycles 8, 65-80.

Anderson, T.R., Williams, B., 1998. Modelling the seasonal cycle of dissolved organic carbon at Station E1 in the English Channel. Estuarine, Coastal and Shelf Science 46, 93-109.

Banse, K., 1994. Uptake of inorganic carbon and nitrate by marine plankton and the Redfield ratio. Global Biogeochemical Cycles 8, 81-84.

Brun, R., Kuhni, M., Siegrist, H., Gujer, W., Reichert, P., 2002. Practical identitfiability of ASM2D parameters systematic selection and tuning of parameter subsets. Water Research 36, 4113-4127.

Buitenhuis, E., Van Bleijswijk, J., Bakker, D., Veldhuis, M., 1996. Trends in inorganic and organic carbon in a bloom of Emiliania huxleyi in the North Sea. Marine Ecology Progress Series 143, 271-282.

Buitenhuis, E., Wal, V.D., De Baar, H., 2001. Blooms of Emiliania huxleyi are sinks of atmospheric carbon dioxide: a field and mesocosm study derived simulation. Global Biogeochemical Cycles 15 (3), 577-587.

Delille, B., Harlay, J., Zondervan, I., Jacquet, S., Chou, L., Wollast, R., Bellerby, R., Frankignoulle, M., Vieira Borges, A., Riebesell, U., Gattuso, J.-P., 2005. Response of primary production and calcification to changes of $\mathrm{pCO}_{2}$ during experimental blooms of the coccolithophorid Emiliania huxleyi. Global Biogeochemical Cycles 19, GB2023. doi:10.1029/2004GB002318.

Engel, A., Schartau, M., 1999. Influence of transparent exopolymer particles (TEP) on sinking velocity of Nitzschia closterium aggregates. Marine Ecology Progress Series 182, 69-76.

Engel, A., Thoms, S., Riebesell, U., Rochelle-Newall, E., Zondervan, I., 2004a. Polysaccharide aggregation as a potential sink of marine dissolved organic carbon. Nature 428, 929-932.

Engel, A., Delille, B., Jacquet, S., Riebesell, U., Rochelle-Newall, E., Terbrüggen, A., Zondervan, I., 2004b. TEP and DOC production by Emiliania huxleyi exposed to different $\mathrm{CO}_{2}$ concentrations: a mesocosm experiment. Aquatic Microbial Ecology 34 (1), 93-104.

Engel, A., Zondervan, I., Aerts, K., Beaufort, L., Benthien, A., Chou, L., Delille, B., Gattuso, J.-P., Harlay, J., Heemann, C., Hoffmann, L., Jacquet, S., Nejstgaard, J., Pizay, M.-D. Rochelle-Newall, E., Schneider, U., Terbrueggen, A., Riebesell, U., 2005. Testing the direct effect of $\mathrm{CO}_{2}$ concentration on a bloom of the coccolithophorid Emiliania huxleyi in mesocosm experiments. Limnology and Oceanography 50 (2), 493-507.
Engel, A., Schulz, K.G., Riebesell, U., Bellerby, R., Delille, B., Schartau, M., 2008. Effects of $\mathrm{CO}_{2}$ on particle size distribution and phytoplankton abundance during a mesocosm bloom experiment (PeECE II). Biogeosciences 5 (2), 509-521.

Godoi, R.H.M., et al., 2009. Organic surface coating on coccolithophores-Emiliania huxleyi: its determination and implication in the marine carbon cycle. Microchemical Journal 91 (2), 266-271.

Goldman, J.C., Caron, D.A., Dennett, M.R., 1987. Regulation of gross growth efficiency and ammonium regeneration in bacteria by substrate C:N ratio. Limnology and Oceanography 32, 1232-1239.

Harlay, J., Borges, A.V., Van Der Zee, C., Delille, B., Godoi, R.H.M., Schiettecatte, L.-S., Roevros, N., Aerts, K., Lapernat, P.-E., Rebreanu, L., Groom, S., Daro, M.-H., Van Grieken, R., Chou, L., 2010. Biogeochemical study of a coccolithophorid bloom in the northern Bay of Biscay (NE Atlantic Ocean) in June 2004. Progress in Oceanography 86, 317-336.

Harlay J., L. Chou, C. De Bodt, N. Van Oostende, J. Piontek, K. Suykens, A. Engel, K. Sabbe, S. Groom, B. Delille, A.V. Borges (2011) Biogeochemistry and carbon mass balance of a coccolithophore bloom in the northern Bay of Biscay (June 2006), Deep-Sea Research I, accepted

Jacquet, S., Heldal, M., Iglesias-Rodriguez, D., Larsen, A., Wilson, W., Bratbak, G., 2002. Flow cytometric analysis of an emiliana huxleyi bloom terminated by viral infection. Aquatic Microbial Ecology 27, 111-124.

Keir, R.S., 1980. The dissolution kinetics of biogenic calcium carbonates in seawater. Geochim. Cosmochim. Acta 44, 241-252.

Lancelot, C., Stavena, J., Van Eeckhout, D., Beckers, J., Stanev, E., 2002. Modelling the danube influenced north-western continental shelf of the black sea. Ecosystem response to changes in nutrient delivery by danube river after its damming in 1972. Estuarine, Coastal and Shelf Science 54, 473-499.

Mehrbach, C., Culberson, C., Hawley, J., Pytkowicz, R., 1973. Measurement of the apparent dissociation constants of carbonic acid in seawater at atmospheric pressure. Limnology and Oceanography 18, 897-907.

Merico, A., Tyrrell, T., Lessard, E., Oguz, T., Stabeno, P., Zeeman, S., Whitledge, T., 2004. Modelling phytoplankton succession on the bering sea shelf : role of the climate influences and trophic interactions in generating Emiliania huxleyi blooms 19972000. Deep-Sea Research Part I. doi:10.1016/j.dsr.2004.07.003.

Millero, F., 1995. Thermodynamics of the carbon dioxide system in the oceans. Geochimica et Cosmochimica Acta 59 (4), 661-677.

Morse, J.W., Arvidson, R.S., 2002. Dissolution kinetics of major sedimentary carbonate minerals. Earth Science Reviews 58, 51-84

Oguz, T., Merico, A., 2006. Factors controlling the summer Emiliania huxleyi bloom in the black sea: a modelling study. Journal of Marine Systems 59. doi:10.1016/j. jmarsys.2005.08.002:173-188.

Paasche, E., 2002. Review of the coccolithophorid Emiliania huxleyi (prymnesiophyceae), with a particular reference to growth, coccolith formation, and calcificationphotosynthesis interactions. Phycologia 40 (6), 503-529.

Passow, U., 2002. Transparent exopolymer particles (TEP) in aquatic environments. Progress in Oceanography 55, 287-333.

Rochelle-Newall, E., Delille, B., et al., 2004. Chromophoric dissolved organic matter in experimental mesocosms maintained under different $\mathrm{pCO}_{2}$ levels. Marine Ecology Progress Series 272, 25-31.

Schartau, M., Engel, A., Schröter, J., Thoms, S., Völker, C., Wolf-Gladrow, D., 2007. Modelling carbon overconsumption and the formation of extracellular particulate organic carbon. Biogeosciences 4, 433-454.

Shaked, Y., Xu, Y., Leblanc, K., Morel, F., 2006. Zinc availability and alkaline phosphatase activity in Emiliania huxleyi: implications for Zn-P co-limitation in the ocean. Limnology and Oceanography 51 (1), 299-309.

Soetaert, K., Herman, P.M.J., Middelburg, J.J., Heip, C., Smith, C.L., Tett, P., Wild-Allen, K., 2001. Numerical modelling of the shelf break ecosystem: reproducing benthic and pelagic measurements. Deep-Sea Research II 48, 3141-3177.

Soetaert, K., deClippele, V., Herman, P., 2002. Femme, a flexible environment for mathematically modelling the environment. Ecological Modelling 151, 177-193.

Soetaert, K., Hofmann, F., Middelburg, J., Meysman, J., Greenwood, J., 2007. The effect of biogeochemical processes on $\mathrm{pH}$. Marine Chemistry. doi:10.1016/j. marchem.2006.12.012.

Suykens, K., Delille, B., Chou, L., De Bodt, C., Harlay, J., Borges, A.V., 2010. Dissolved inorganic carbon dynamics and air-sea carbon dioxide fluxes during coccolithophore blooms in the Northwest European continental margin (northern Bay of Biscay). Global Biogeochemical Cycles 24, GB3022. doi:10.1029/2009GB003730.

Tett, P., Wilson, H., 2000. From biochemical to ecological models of marine phytoplankton. Journal of Marine Systems 25, 431-446.

Toggweiller, J., 1993. Carbon overconsumption. Nature 363, 210-211.

Tyrrell, T., Taylor, A., 1996. A modelling study of Emiliania huxleyi in the NE Atlantic. Journal of Marine Systems 9, 83-112.

Van Den Meersche, K., Middelburg, J., Soetaert, K., Van Rijswijk, P., Boschker, H., Heip, C., 2004. Carbon-nitrogen coupling and algal-bacterial interactions during an experimental bloom: modelling a ${ }^{13} \mathrm{C}$ tracer experiment. Limnology and Oceanography $49,862-878$.

Wanninkhof, R., 1992. Relationship between wind speed and gas exchange over the ocean. Journal of Geophysical Research 97, 7373-7382.

Weiss, R.F., 1974. Carbon dioxide in water and seawater: the solubility of a non-ideal gas. Marine Chemistry 2, 203-215

Xu, Y., Wahlund, T., Feng, L., Shaked, Y., Morel, F., 2006. A novel alkaline phosphatase in the coccolithophore Emiliania huxleyi (prymnesiophyceae) and its regulation by phosphorus. Journal of Phycology 42 (4), 835-844.

Zondervan, I., 2007. The effects of light, macronutrients, trace metals and $\mathrm{CO}_{2}$ on the production of calcium carbonate and organic carbon in coccolithophores. Deep-Sea Research II 54, 521-537. 